OPEN ACCESS

Edited by:

Emanuele Pelosi,

The University of Queensland,

Australia

Reviewed by:

Daniel J. Bernard,

McGill University,

Canada

Yoshihisa Uenoyama,

Nagoya University,

Japan

*Correspondence: Jian Fei

jfei@tongji.edu.cn

Ruling Shen

shenruling@slarc.org.cn

Specialty section:

This article was submitted to

Reproduction,

a section of the journal

Frontiers in Endocrinology

Received: 01 December 2020

Accepted: 10 May 2021

Published: 31 May 2021

Citation:

Guo Y, Wu Y, Shi J, Zhuang H,

Ci L, Huang Q, Wan Z, Yang $H$,

Zhang $M$, Tan Y, Sun R, Xu L,

Wang Z, Shen $R$ and Fei J (2021)

miR-29a/b, Regulates

the Luteinizing Hormone Secretion

and Affects Mouse Ovulation.

Front. Endocrinol. 12:636220. doi: 10.3389/fendo.2021.636220

\section{miR-29a/b 1 Regulates the Luteinizing Hormone Secretion and Affects Mouse Ovulation}

\author{
Yang Guo ${ }^{1,2}$, Youbing $W_{u^{3}}$, Jiahao Shi ${ }^{1}$, Hua Zhuang ${ }^{3}$, Lei Ci ${ }^{1,3}$, Qin Huang ${ }^{3}$, \\ Zhipeng Wan ${ }^{1,3}$, Hua Yang ${ }^{1}$, Mengjie Zhang ${ }^{1}$, Yutong $\operatorname{Tan}^{1}$, Ruilin Sun ${ }^{3}$, Leon Xu ${ }^{1}$, \\ Zhugang Wang ${ }^{4}$, Ruling Shen ${ }^{1,2^{*}}$ and Jian Fei ${ }^{1,3^{*}}$ \\ 1 School of Life Science and Technology, Tongji University, Shanghai, China, ${ }^{2}$ Shanghai Lab, Animal Research Center, \\ Shanghai, China, ${ }^{3}$ Shanghai Model Organisms, Shanghai, China, ${ }^{4}$ Department of Medicine, Ruijin Hospital, Shanghai Jiao \\ Tong University, Shanghai, China
}

$m i R-29 a / b$, was reportedly involved in the regulation of the reproductive function in female mice, but the underlying molecular mechanisms are not clear. In this study, female mice lacking miR-29a/b, showed a delay in vaginal opening, irregular estrous cycles, ovulation disorder and subfertility. The level of luteinizing hormone $(\mathrm{LH})$ was significantly lower in plasma but higher in pituitary of mutant mice. However, egg development was normal in mutant mice and the ovulation disorder could be rescued by the superovulation treatment. These results suggested that the LH secretion was impaired in mutant mice. Further studies showed that deficiency of miR-29a/ $b_{1}$ in mice resulted in an abnormal expression of a number of proteins involved in vesicular transport and exocytosis in the pituitary, indicating the mutant mice had insufficient LH secretion. However, the detailed mechanism needs more research.

Keywords: $m i R-29 a / b_{1}$, knockout, LH, ovulation, reproduction

\section{INTRODUCTION}

The $m i R-29$ family consists of three related mature miRNAs, $m i R-29 a, m i R-29 b$ and $m i R-29 c$, which are processed from two precursor sequences located at two distinct genomic clusters of $m i R-29 a / b_{1}$ and $m i R-29 b_{2} / c$. Members of the miR-29 family are ubiquitously expressed, have considerable overall sequence homology with the same seed sequence. Although they have similar tissue expression patterns, miR-29a is the dominant member accounting for more than $50 \%$ of total miR-29 expressed in all tissues (1). miR-29 play important roles in regulating a number of physiological and pathological processes, including metabolism (1-3), inflammation $(4,5)$, fibrosis (6), cancer (7) and neurodegeneration (8).

As a potential clinical marker or new form of nucleic acid drug, much attention has been paid to miR-29 research $(9,10), m i R-29$ deficiency causes a wide range of physiological defects in mice. Premature cardiac fibrosis and atherosclerotic plaque remodeling is considered as a result of abnormal expression of miR-29 target genes Col4a (11) and ECM (Colla and Col5a) (12), and heart

Abbreviations: miRNA, microRNA; iTRAQ, isobaric tags for relative and absolute quantification; PCR, polymerase chain reaction; $\mathrm{LH}$, luteinizing hormone; FSH, follicle-stimulating hormone; $\mathrm{KO}$, knockout. 
failure and metabolic disorders might be caused by up-regulating the target gene PCG1 $\alpha$ (1). $m i R-29 a$ responsible for repressing LPL in hepatocytes, contributes to physiological lipid distribution and protects hepatocytes from steatosis (13). Homozygous deletion of $m i R-29 a / b_{1}$ in mice led to decreased self-renewal and increased apoptosis in hematopoietic stem cells (HSCs) through up-regulating Dnmt3a (14). In addition, early puberty in hypothalamic $m i R-29$ knockdown females is attributed to ectopic expression of Tbx21, a target gene of miR29 (15). Reproduction in $m i R-29$ brain-specifical knockdown mice was affected in a sex-dependent manner, with female mice exhibiting hyperfertility and males being subfertility (16); however, this result is inconsistent with the sterile phenotype reported in the $m i R-29 a / b_{1}$ knockout mice (1). Therefore, the relationship between $m i R-29 a / b_{1}$ and reproductive function is still not well understood.

In this work, we revealed that female $m i R-29 a / b_{1}$ knockout mice exhibit severe fertility problems. We proposed that the lack of $m i R-29 a / b_{1}$ in female mice may interfere with the secretion of luteinizing hormone in the pituitary, leading to ovulation failure and a subfertile phenotype.

\section{MATERIALS AND METHODS}

\section{Generation of $m i R-29 a / b_{1}$ Knockout Mice}

A $m i R-29 a / b_{1}$ knockout mouse line was established using CRISPR/Cas9 gene editing technology and was supplied by Shanghai Center for Model Organisms (SMOC) (17). miR-29al $b_{1}{ }^{-1-}$ homozygous animals and their wild-type littermates were obtained by mating corresponding heterozygotes with each other. Genomic DNA was extracted from tail biopsies, using magnetic bead DNA isolation Kit (DE0596D, EmerTher, Shanghai). PCR was adopted for genotyping using $2 \times$ Taq Plus Master Mix (P212-01, Vazyme) under the following conditions: denaturation at $98^{\circ} \mathrm{C}$ for 2 minutes, then 35 cycles of $98^{\circ} \mathrm{C}$ for 10 seconds, annealing at $63^{\circ} \mathrm{C}$ for 15 seconds, and extension at $68^{\circ} \mathrm{C}$ for 60 seconds. Primers used for genotyping are listed in Table S1.

\section{Animals}

All animals were housed in a specific pathogen-free environment ( $12 \mathrm{~h}$ light $/ 2 \mathrm{~h}$ dark with lights on at $7.00 \mathrm{~h}$ at $21 \pm 2^{\circ} \mathrm{C}$ ) with food and water ad libitum. This study was performed in strict accordance with institutional guidelines and approved by the Institutional Animal Care and Use Committee of Shanghai Model Organisms, and the IACUC permit number is 20090002.

\section{Fertility Assessment}

8-week-old $m i R-29 a / b_{1} \mathrm{KO}$ and wild-type virgin female or male mice were bred with wild-type male or female mice with known fertility at a proportion of $\$ 2$ : $\widehat{\jmath} 1$, and vaginal plug formation was examined every morning for 20 consecutive days. Pregnant female mice were separated and pups were recorded, while nonpregnant mice continued to mate. Female or male mice that did not conceive within 1 month of mating were defined as infertile.

\section{Sexual Maturity and Vaginal Smear}

Female $m i R-29 a / b_{1} \mathrm{KO}$ and wild-type mice from the age of 3week-old were examined twice daily with respect to on vaginal opening as a marker of rodent sexual maturity. The date of vaginal opening in each mouse was recorded. Female $m i R-29 a / b_{1}$ $\mathrm{KO}$ and wild-type (8-10 weeks old for each genotype) mice were caged individually for 3 weeks and at least two full estrous cycles were obtained in each mouse.

Vaginal smears were collected daily and the determination of estrous cycle was evaluated microscopically with the vaginal epithelium. The vaginal epithelium obtained from the vaginal opening by gently eluting $10 \mu \mathrm{l}$ of physiological saline solution 2-4 times, then the vaginal epithelium transferred onto a microscopic slide and dried at room temperature and fixed with $100 \%$ methanol. The slides were stained with Wright's Giemsa (BASO) stain and examined with light microscopy. Proestrus cells are well-formed nucleated epithelial cells. Animals with $85 \%$ superficial epithelial cells were considered to be estrus. During metestrus, cornified squamous epithelial cells often in fragments, as well as leukocytes, may be observed. Otherwise, the predominant presence of leukocytes in the cytological smear was identified as diestrus.

\section{Ovariectomy}

Adult (8-10 weeks) $m i R-29 a / b_{1}$ KO and control females in diestrus morning were injected subcutaneously with pentobarbital (effective dose $320 \mathrm{mg} / \mathrm{kg}$ ). Mice were deeply anesthetized and placed on a heating pad. The back skin was shaved and cleaned. About $1.0 \mathrm{~cm}$ long incision was made through the muscle layer above the ovaries on each side of the midline. Through the incision, the ovaries were gently pulled outside the body and removed by cauterization below the oviduct. The skin incision was closed with sutures. The mice were left to recover on a heating pad. Adult sham-operated mice were in diestrus on the day of recording as determined by vaginal cytology. Sham-treated animals were processed in the same way, except for the intact ovaries retained. Mice were killed 7 days post-surgery, and their serum were measured for $\mathrm{LH}$ and FSH levels.

\section{Hormone Measurement}

For hormone measurement, orbital blood was collected in the morning (10.00 h-11.00 h) and evening (18.00 h-19.00h) (18) from freely-moving conscious animals during randomly estrous cycle stages, and were kept at room temperature for 30 minutes. Serum was obtained by centrifuging for 15 minutes at $3000 \mathrm{~g}$ at $4^{\circ} \mathrm{C}$ and was stored at $-80^{\circ} \mathrm{C}$ until analysis. Serum levels of hormone and pituitary proteins LH level were analyzed by Shanghai WESTANG BIO-TECH cooperation using enzymelinked immunosorbent assay (ELISA). The minimum detectable level of the $\mathrm{LH}$ assay was $0.1 \mathrm{mIU} / \mathrm{ml}$ and the intra-and interassay coefficients of variation were $9.9 \%$ and $8.3 \%$. The minimum detectable level of the FSH assay was $1 \mathrm{mIU} / \mathrm{ml}$ and the intra-and inter-assay coefficients of variation were $9.8 \%$ and $8.6 \%$, The minimum detectable level of the estrogen assay was $30 \mathrm{pg} / \mathrm{ml}$ and the intra-and inter-assay coefficients of variation were $9.3 \%$ and 
$8.5 \%$, The minimum detectable level of the progesterone assay was $0.2 \mathrm{ng} / \mathrm{ml}$ and the intra-and inter-assay coefficients of variation were $9.5 \%$ and $8.3 \%$, The minimum detectable level of the testosterone assay was $0.1 \mathrm{ng} / \mathrm{ml}$ and the intra-and interassay coefficients of variation were $9.4 \%$ and $8.2 \%$, respectively.

\section{GnRH Challenge}

Animals received an intraperitoneally injection with $125 \mathrm{ng} / \mathrm{g}$ (19) exogenous GnRH (L7134, Sigma-Aldrich, St Louis, MO, USA) or saline vehicle. Twenty minutes after GnRH or saline injection, orbital blood was collected, and the resultant serum samples were stored at $-80^{\circ} \mathrm{C}$ for subsequent human-LH radioimmunoassay (RIA, performed by Beijing North Institute Biological Technology, Beijing, China) (20), with sensitivity and intra- and inter-assay coefficient of variation for LH of $0.5 \mathrm{mIU} /$ $\mathrm{ml}, 15 \%$ and $20 \%$, respectively.

\section{Superovulation and Oocyte Collection}

Superovulation: To induce superovulation, 8-week-old mice were intraperitoneally injected with $5 \mathrm{IU}$ pregnant mare serum gonadotropin (PMSG, Sigma) at afternoon (15:00h-16:00 h), followed by 5 IU human chorionic gonadotropin (hCG, Sigma) 48 hour later to trigger oocyte maturation and ovulation. Female mice were mated with 10-week-old fertile wild-type males $16 \mathrm{~h}$ after injection and checked for vaginal plug formation the next morning.

Oocyte collection: Super ovulated or natural mated mice with a visible plug were sacrificed by cervical dislocation, the ovaries were removed and the ampulla was collected. Oocytes were harvested in M2 media and quantified by microscopy (Nikon SMZ800) following brief digestion in hyaluronidase $(800 \mathrm{IU} / \mathrm{ml}$, Sigma) to strip cumulus and pipetting for 30-60 s. Oocytes were washed 5 times with PBS. The washed oocytes were transferred to M16 media and cultured overnight, and two-cell stage embryos were counted in the next morning.

\section{LC-MS/MS Analysis}

Total pituitary (P) protein from wild-type and $m i R-29 a / b_{1} \mathrm{KO}$ females ( 8 weeks, $n=3$ ) were isolated and labelled with iTRAQ reagents $114,115,116,117,118,119,120$ or 121 , respectively, followed by Liquid Chromatography with tandem mass spectrometry (LC-MS/MS) (Shanghai Wayen Biotechnologies Inc.). The mass spectrometry proteomics data have been deposited to the ProteomeXchange Consortium via the PRIDE (21) partner repository with the dataset identifier PXD017106.

\section{Histological Analysis and Follicles Count}

Wild-type and $m i R-29 a / b_{1}$ KO were euthanized and transcardially perfused with cold saline, followed by $4 \%$ paraformaldehyde $0.1 \mathrm{M}$ phosphate buffer (PFA). Brain, pituitary and ovary were collected and fixed overnight at $4^{\circ} \mathrm{C}$. Paraffin-embedded ovary samples were serially sectioned at 4 $\mu \mathrm{m}$-thick sections. Brain coronal $(20 \mu \mathrm{m})$ slices were cut with a Leica CM1950 following by dehydration in 30\% sucrose saline solution.

Pituitary and ovary stained with hematoxylin and eosin using standard histological techniques (Servicebio). Stained sections were scanned using LEICA CTR6000 with a 10X, 20X and 40X objective. Ovarian follicles at different developmental stages were classified and quantified in serial sections according to the Pedersen and Peters method (22). To avoid double counting of follicles across sections, only follicles containing oocyte with a clearly visible nucleus were scored (23), and follicles were counted in every fifth serial section. Any follicle also appearing in the adjacent lookup section was not counted. The entire section was analyzed without subsampling. Each ovary was coded with no information about genotype group for blind counters and prevent bias. The mean count per section was calculated. All follicle types were summed together to determine the total number of follicles.

For immunohistochemistry, sections were subjected to antigen retrieval by incubation in $10 \mathrm{mM}$ sodium citrate, $\mathrm{pH}$ 7.0 , for 10 minutes at $95^{\circ} \mathrm{C}$. The endogenous peroxidase activity of the sections was quenched with $3 \% \mathrm{H}_{2} \mathrm{O}_{2}$ treatment (Sangon Biotech, Shanghai). Immunohistochemical staining was performed using mouse anti-Lutropin beta antibody (1:500, SANTA CRUZ, sc-373941) or rabbit anti-GnRHR antibody $(24,25)$ (1:100, Proteintech, 19950-1-AP) and HRP-conjugated donkey anti-mouse IgG (1:1000, ThermoFisher, A16017) or donkey anti-rabbit IgG (1:1000, ThermoFisher, A16035) for lutropin and GnRHR antibody.

For immunofluorescence, brain and pituitary sections permeabilized by incubation with $0.1 \%$ Triton X-100 in PBS for 10 minutes at room temperature. After permeabilization, the sections were washed three times in PBST, and blocked with 5\% normal donkey serum in PBS for $1 \mathrm{~h}$ at room temperature, then were incubated with mouse anti-Lutropin beta antibody (1:1000, SANTA CRUZ, sc-373941), rabbit anti-GnRH1 (1:500, Immunostar, PA1-121) or rabbit anti-GnRHR antibody (26) (1:100, Proteintech, 19950-1-AP) overnight at $4^{\circ} \mathrm{C}$, followed by staining with Alexa Fluor 647-conjugated donkey anti-mouse antibody (Invitrogen Molecular Probes) or Alexa Fluor 594conjugated donkey anti-rabbit (Invitrogen Molecular Probes) antibody and DAPI dye to stain nuclei. The mouse liver and lung tissues were selected to negative control for GnRHR and Lutropin beta antibody respectively.

Stained sections were scanned using the $40 \mathrm{X}$ objective of a Zeiss Confocal microscope (LSM880). The area fractions of positive cells relative to entire area were determined using ImageJ (Fiji, NIH) software. Cell location was mapped to the atlas (27).

\section{Real-Time Quantitative PCR}

Total RNA was isolated using TRIzol (Tiangen Biotech, Beijing) according to the manufacturer's instructions and kept at $-80^{\circ} \mathrm{C}$ subsequent for use. For microRNA measurement, $2 \mu \mathrm{g}$ total RNA was transcribed into cDNA using the miRcute Plus miRNA First-Strand cDNA Synthesis Kit (Tiangen Biotech, Beijing). Expression level of mature $m i R-29 a, m i R-29 b$ and $m i R$ $29 c$ were measured using miRcute Plus miRNA qPCR Detection (Tiangen Biotech, Beijing). U6 snRNA was used for normalization.

For mRNA measurement, total RNA $(2 \mu \mathrm{g})$ from each sample was transcribed by using EasyScript First-Strand cDNA 
Synthesis SuperMix (TransGen Biotech, Beijing), and mRNA levels of target genes were detected using TransStart Tip Green qPCR SuperMix (TransGen Biotech, Beijing) according to the manufacturer's instructions. Murine $\beta$-actin was used as a reference to normalize target gene expression levels. Real-time PCR amplification was performed using the Realplex system (Applied Biosystems QuantStudio3, ThermoFisher Scientific). The sequences of the specific primers used are listed in Supplementary Material, Table S1. RNA levels were calculated using the $2^{-\Delta \mathrm{CT}}$ method, where CT is the cycle threshold (28). Melting curve analysis for each primer set revealed only one peak for each product, and the sizes of PCR products were confirmed by comparing sizes with a commercial ladder after agarose gel electrophoresis. PCR products were further confirmed by sequencing.

\section{Western Blot}

Mice were euthanized and tissues were collected. Total tissue protein was extracted using RIPA buffer (ThermoFisher scientific) containing protease and phosphatase inhibitor cocktails (Selleck Chemicals). Protein concentration was quantified using the Enhanced BCA Protein Assay Kit (Beyotime). Protein $(20 \mu \mathrm{g})$ from each sample was separated on 4\%-20\% SDS-PAGE (GenScript) and transferred onto nitrocellulose membranes (GE Healthcare). Membranes were blocked with Western BLoT Blocking Buffer (Protein Free) (Takara) for $1 \mathrm{~h}$ at room temperature and then incubated with primary antibodies, Lutropin beta (1:1000, SANTA CRUZ, sc$373941)$ or anti- $\beta$-actin (1:1000, Santa Cruz, sc-47778) diluted in Western BLoT Immuno Booster PF (Takara) at $4^{\circ} \mathrm{C}$ overnight. After washing with TBST three times, membranes were incubated with fluorescent-conjugated secondary antibody for 1 h (1:10000, LI-COR Biosciences). Quantitative detection of protein expression was then performed using the Odyssey Infrared Imaging system (LI-COR Biosciences) and analyzed with Image J software (National Institutes of Health, Bethesda, MD, USA).

\section{Statistical Analysis}

Data analysis was performed using GraphPad Prism 7 (GraphPad software Inc.). Data are expressed as the mean \pm SEM. Difference in mean values between two groups were analyzed using the Student's t-test (continuous variables) or Mann-Whitney test (discrete variables). For comparisons involving more than two groups, ANOVA (continuous variables) or Kruskal-Wallis (discrete variables) with post hoc testing was used, and survival profiles were constructed by
Kaplan-Meyer survival analysis. Statistically significant differences are shown with asterisks $\left({ }^{*} p<0.05,{ }^{* *} p<0.01\right.$, ${ }^{* * *} p<0.001$, and $\left.{ }^{* * * *} p<0.0001\right)$.

\section{RESULTS}

\section{Genetic Ablation of $m i R-29 a / b_{1}$ Leads to Female Sterility}

A conventional $m i R-29 a / b_{1}$ knockout mouse line $\left(m i R-29 a / b_{1}\right.$ KO) was previously established using CRISPR/Cas9 methods (17). The genotyping and the expression of $m i R-29$ in different genotypes of mice were detected by PCR and real-time PCR, respectively (Figure S1). To understand the role of $m i R-29 a / b_{1}$ in fertility, the reproductive ability of $m i R-29 a / b_{1} \mathrm{KO}$ mice was evaluated. For data in Table 1, of the 25 females tested, 23 were sterile. The two pregnant $m i R-29 a / b_{1} \mathrm{KO}$ female mice gave birth to two offspring each and were not subsequently pregnant again. Among males, $66.7 \% m i R-29 a / b_{1}$ KO were still fertile. However, female $m i R-29 a / b_{1}$ KO mice exhibited serious reproductive problems. Vaginal plugs were checked to study the mating behavior. miR-29a/b $\mathrm{KO}$ females had a significant lower mating frequency compared to wild-type females (Table 1), suggesting abnormal sexual maturity and estrous cycle. Sexual maturity indicated by vaginal opening occurred 5 days later in $m i R-29 a / b_{1}$ KO female mice (postnatal day 28) compared to wild-type littermates (postnatal day 23) (Figure 1A). At the time of puberty onset, the mutant mice are significantly lighter than wild-type mice (Figure 1B). Meanwhile, abnormal estrous cycle with less time in estrus and metestrus and significantly more time in diestrus was observed in $m i R-29 a / b_{1} \mathrm{KO}$ female mice. (Figures 1B, C and Figure S2). RT-PCR analysis revealed that expression of $m i R-29 a$ periodically changed in pituitary and ovarian tissues (Figure S3A), suggesting that $m i R-29 a / b_{1}$ may play a role in the estrous period in mammals. Taken together, these data illustrate that loss of $m i R-29 a / b_{1}$ induces growth retardation in mutant mice and subfertility in females.

\section{miR-29a/b Gene Knockout Leads to Decreased Plasma LH Level and Ovulation Disorder}

Ovary and uteri weight in $m i R-29 a / b_{1} \mathrm{KO}$ females were significantly reduced compared to wild-type females (Figures 2A, B), whereas, in males, testis and seminal pouch in $m i R-29 a / b_{1} \mathrm{KO}$ mice and wild-type counterparts showed no difference (Figure S4). Fertilized eggs were collected from the

TABLE 1 | Fertility assessment. Body weight, number of plugs, offspring and pregnancy rate based on mating of wild-type male and female mice.

\begin{tabular}{|c|c|c|c|c|}
\hline $\begin{array}{l}\text { Fertility assessment } \\
\text { Genotype }\end{array}$ & \multicolumn{2}{|c|}{ Females } & \multicolumn{2}{|c|}{ Males } \\
\hline Body weight (g) & $16.35 \pm 0.2228$ & $20.72 \pm 0.9777$ & $20.02 \pm 1.076$ & $23.7 \pm 0.6186$ \\
\hline Mean litter size & 2 & 7.6 & 5.5 & 7.6 \\
\hline Pregnancies rate (\%) & $8^{\star \star \star \star}$ & 91.7 & $66.7^{\star \star}$ & 83.3 \\
\hline
\end{tabular}

${ }^{* *} p<0.01,{ }^{* * * *} p<0.0001$. 
A

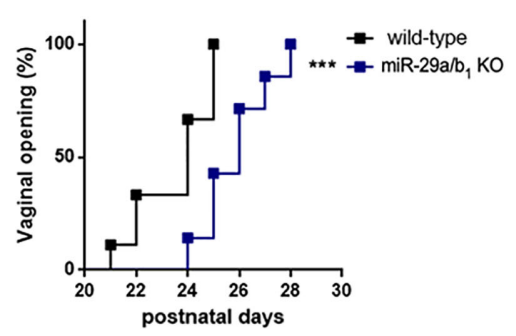

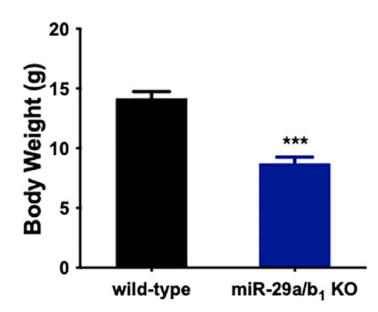

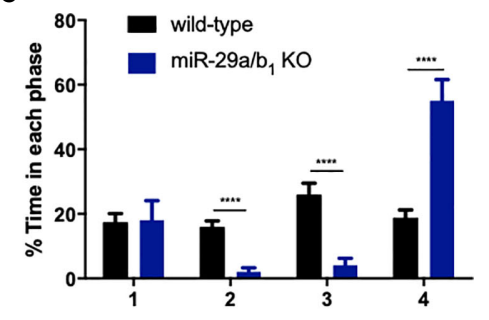

FIGURE 1 | Determination of pubertal onset and estrous cycle in miR-29a/b, KO females. (A) Pubertal onset was determined by vaginal opening in wild-type and miR-29a/b, KO mice ( $\mathrm{n}=8$ ). (B) Body weight of mice at the time of puberty onset (wild-type: $14.18 \pm 0.5660, m i R-29 a / b, K O: 8.74 \pm 0.5202, p=0.0001, n=5)$. (C) Estrous cycle quantitative measurements on wild-type and miR-29a/b, KO females $(1: p=0.9133,2-4: p<0.0001)$. ${ }^{\star \star *} p<0.001$, ${ }^{\star \star * *} p<0.0001$.

oviducts of wild-type and $m i R-29 a / b_{1}$ KO females with vaginal plug after mating with wild-type males. In 20 females $m i R-29 a / b_{1}$ KO mice, only 2 oocytes were found and with no two-cell embryos the next day, while among five wild-type mice, 34 oocytes and 19 two-cell embryos were collected (Figure 3A). Histomorphometric analysis revealed that mutant ovaries contained normal primordial follicles, a similar number of secondary follicles with normal oocyte and a thick granulosa cell layer, indicating that the early follicles developed normally, but lacked corpora lutea formation (Figures 3B-D). These results suggest that subfertility of the mutant female mice may be caused by an ovulation disorder.

In females, hormonal control of the estrous cycle and ovulation is essential for the establishment of maturation and fertility in mammals (29). Thus, we examined hormone levels in the serum of wild-type and $m i R-29 a / b_{1}$ KO female mice. In the female $m i R-29 a / b_{1}$ KO mice, significant decreases in the serum LH and progesterone $\left(\mathrm{P}_{4}\right)$ (Figure 4A) were observed, while there was no apparent difference in serum content of folliclestimulating hormone $(\mathrm{FSH})$ or Testosterone $(\mathrm{T})$ or Estradiol $\left(\mathrm{E}_{2}\right)$ compared to wild-type mice (Figures S5A-C). Cyp $19 a_{1}$ and Cyp $17 a_{1}$, encoding enzymes involved in estradiol and testosterone synthesis, were expressed at identical levels in ovaries from the two groups of mice, while the Cyp11a, which essential to the level of sex hormones, was significantly decreased in ovaries from mutant mice (Figure S5D). These results indicated that impaired corpora lutea formation in $m i R-29 a / b_{1}$ KO mice might be caused by a shortage of LH. This speculation was further confirmed by the superovulation experiment. Ovulation in the mutant mice was rescued by exogenous gonadotropin injection, indicating that responses to $\mathrm{LH}$ stimulation were not irreversibly lost in these mutant animals (Figure 4B). Ovaries from superovulated adult $m i R-29 a / b_{1} \mathrm{KO}$ mice showed normal morphology, and the corpora lutea were formed (Figure 4C).

To determine whether the central regulated mechanisms mediating ovulation were altered in $m i R-29 a / b_{1}$ KO mice, females were subsequently treated with an intraperitoneally injection of $125 \mathrm{ng} / \mathrm{g} \mathrm{GnRH}$ or saline vehicle at $10.00 \mathrm{AM}$. Normal GnRH responsiveness was observed in $m i R-29 a / b_{1} \mathrm{KO}$ pituitary, but serum LH level in $m i R-29 a / b_{1}$ KO females remained markedly below the levels observed in wild-type littermates (Figure 4D). Furthermore, The GnRHRimmunoreactivity in the pituitary of $m i R-29 a / b_{1} \mathrm{KO}$ mice was increased compared to wild-type mice (Figures 5A, B), Again, to assess the impact of hyperstimulation with endogenous $\mathrm{GnRH}$ modulated by estrogen (30-33), female control and $m i R-29 a / b_{1}$ $\mathrm{KO}$ animals were castrated or underwent a sham surgery.
A

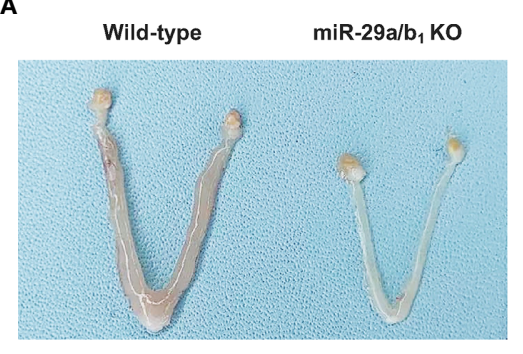

B

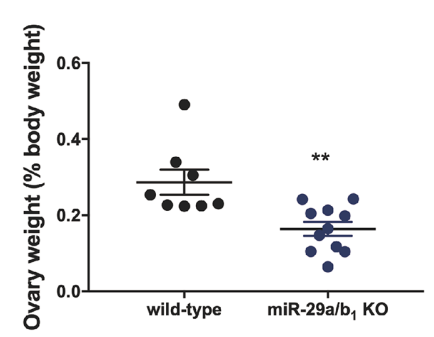

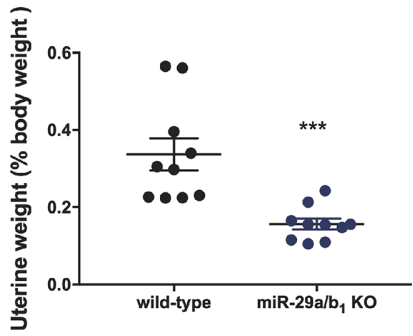

FIGURE 2 | Morphological study of reproductive system. (A, B) Macroscopic images, wet ovaries and uteri weight in females, normalized to body weight in the same animals (ovary: wild-type: $0.2868 \pm 0.03286, \mathrm{n}=8$, miR-29a/b, KO: $0.164 \pm 0.01834, \mathrm{n}=11, p=0.0028$; uteri: wild-type: $0.3369 \pm 0.04175, \mathrm{miR}-29 \mathrm{a} / \mathrm{b}, \mathrm{KO}$ : $0.1564 \pm 0.01394, p=0.007, \mathrm{n}=10) .{ }^{\star \star} p<0.01,{ }^{\star \star} p<0.001$. 
A

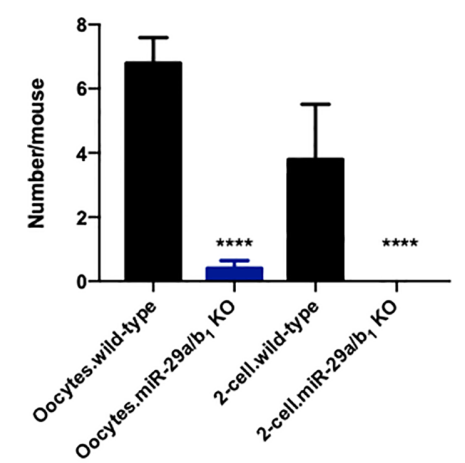

C

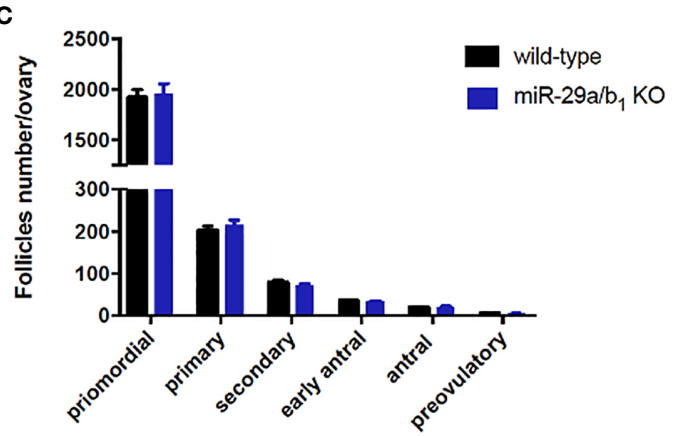

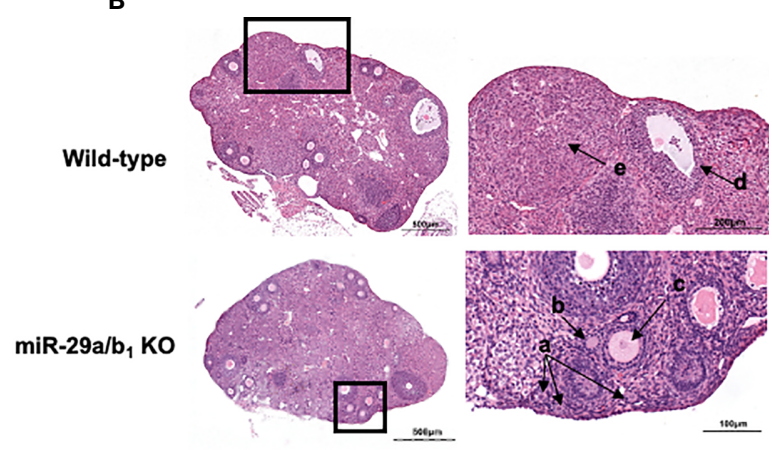

D

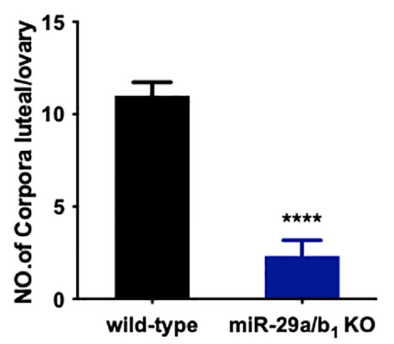

FIGURE 3 | Lacking of miR-29a/b, impairs ovulation in females. (A) Numbers of oocytes and 2-cell embryos in wild-type and miR-29a/b, KO mice during natural ovulation ( $n=5)$. (B) Histological sections of ovaries stained with haematoxylin and eosin (H\&E) in wild-type and miR-29a/b, KO mice. Corpora lutea (CLs) and follicles at different stages are shown at higher magnification and denoted with arrows. a: Primordial follicles; b: Primary follicles; c: Secondary follicles; d: Antral follicles; e: Corpora lutea. (C) Numbers of follicles at different stages in ovaries from wild-type $(n=10)$ and miR-29a/b, KO $(n=12)$ mice. Primordial follicles: $p=0.8931$; Primary follicles: $p=0.9802$; Secondary follicles: $p=0.6842$; Early antral follicles: $p=0.5645$; Antral follicles: $p=0.8011$; Preovulatory: $p=0.5081$, respectively. (D) Lack of corpora lutea in the ovaries of $m i R-29 a / b$, KO females $(p<0.0001)$. ${ }^{\star \star \star \star} p<0.0001$.

Animals were euthanized after 7 days, and serum concentrations of LH and FSH were measured. Consistent with control females, castration resulted in an increase in both $\mathrm{LH}$ and FSH compared with sham-operated controls, however, the post-castration rise in LH secretion was blocked in $m i R-29 a / b_{1}$ KO females, while the FSH level was no significant differences in mutant mice serum from controls (Figure 5C). LH levels overall were markable lower in $m i R-29 a / b_{1} \mathrm{KO}$ females relative to controls. There was no apparent difference in Kiss1and Gnrh1, which stimulating secretion of gonadotropin releasing hormone from the hypothalamus (34-37) and luteinizing hormone from the pituitary (35), respectively (Figures 5D, E). These results suggest that ovulation disorder in $m i R-29 a / b_{1}$ KO mice might be caused by dysregulation of related pituitary hormones, especially LH.

\section{Dysregulated Pituitary LH $\beta$ Release in $m i R-29 a / b_{1}$ KO Mice}

$\mathrm{LH}$ is synthesized in and secreted by the pituitary. A lack of $m i R$ $29 a / b_{1}$ was confirmed in mutant pituitary tissues (Figure S3B). The anterior pituitary undergoes rapid proliferation in neonatal mice, subsequently expanding the cells that produce factors required for growth and reproduction (38). Defective anterior pituitary development in animals contributes to many organismlevel developmental defects (39). However, there was no difference in pituitary structure, size or position of the anterior pituitary between wild-type and $m i R-29 a / b_{1}$ KO mice (Figure 6A). No abnormalities were found upon pathological examination of mutant pituitary tissues (Figure 6B). Notably, transcript levels of the $L h \beta$ gene in $m i R-29 a / b_{1}$ KO pituitary did not differ from control animals, but $\mathrm{LH}$ protein level and immunoreactivity were even higher in $\mathrm{KO}$ mice (Figures 6C-F).

To further elucidate the effects of $m i R-29 a / b_{1}$ gene knockout on pituitary function, iTRAQ analysis was performed to compare proteomic changes in the pituitary between mutant and wildtype mice. Total pituitary protein from three biological replicates of each genotype were subjected to LC-MS/MS analysis. The hierarchical clustering profile of differential proteins is shown in the heat map (Figure 7A). A total of 163 cellular proteins were statistically significant altered $(p<0.05)$, including 75 upregulated proteins and 88 downregulated proteins (Figure 7B, Table 2). LH $\beta$ and FSH $\beta$ were significantly increased in the pituitary of $m i R-29 a / b_{1}$ KO mice according to $\mathrm{b} / \mathrm{y}$ ion signal intensity (Figure 7C). Besides, TSH $\beta$ and Cga were also markedly upregulated as a result of the $m i R-29 a / b_{1}$ deficiency (Figures 7C, G). Through GO analysis, altered proteins 


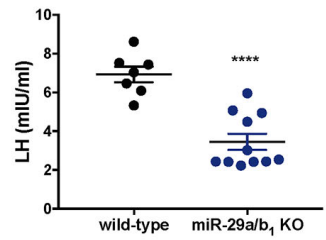

wild-type $\operatorname{miR}^{\prime}-29 a / b_{1}$ KO
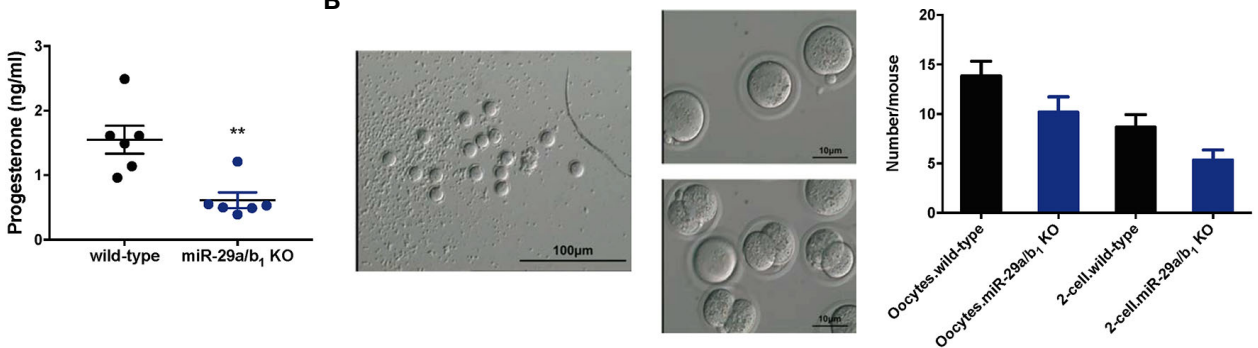

C
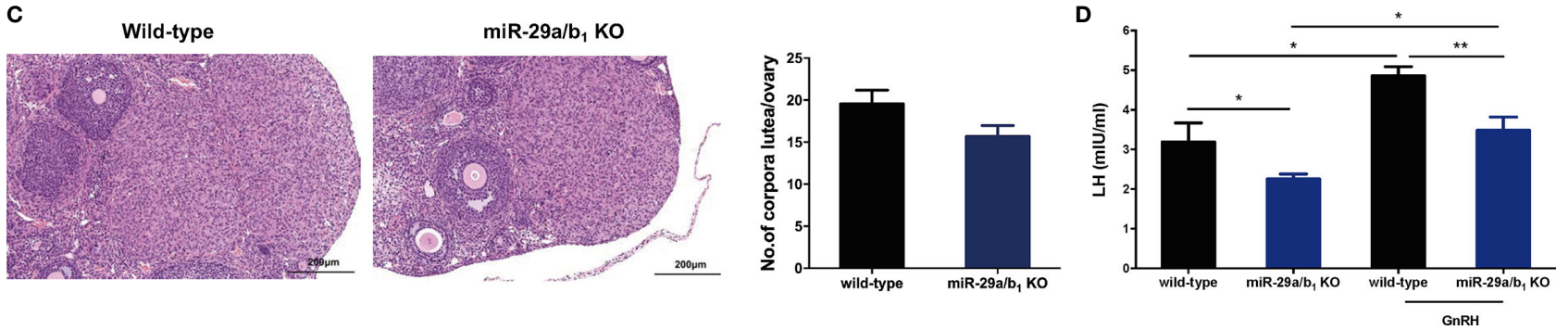

FIGURE 4 Superovulation rescues the failure in corpora lutea formation in miR-29a/b 1 KO mice. (A) Serum LH (left) and progesterone (right) levels were significantly reduced in miR-29a/b, $\mathrm{KO}$ compared to wild-type mice (LH: wild-type: $6.927 \pm 0.4062 \mathrm{mlU} / \mathrm{ml}, \mathrm{miR}-29 \mathrm{a} / \mathrm{b}, \mathrm{KO}: 3.607 \pm 0.5175 \mathrm{mlU} / \mathrm{ml}, p=0.0003$, $\mathrm{n}=7$; progesterone: wild-type: $8.166 \pm 2.072 \mathrm{nmol} / \mathrm{L}, \mathrm{n}=7$, miR-29a/b, KO: $1.062 \pm 0.1181 \mathrm{nmol} / \mathrm{L}, \mathrm{n}=6, p=0.0092)$. (B) Numbers of oocytes and 2-cell embryos obtained in response to superovulation in miR-29a/b, KO and wild-type mice (Oocytes: wild-type: $13.83 \pm 1.493, \mathrm{miR}^{2}-29 \mathrm{a} / \mathrm{b}, \mathrm{KO}: 10.17 \pm 1.558, p=0.1201 ; 2-c e l l$ embryos: wild-type: $\left.8.667 \pm 1.256, \mathrm{miR}-29 \mathrm{a} / \mathrm{b}_{1} \mathrm{KO}: 5.333 \pm 1.022, p=0.0666, \mathrm{n}=6\right)$. (C) Corpora lutea formation in ovaries of miR-29a/b $\mathrm{KO}$ females after superovulation (wild-type: $19.56 \pm 1.634$, miR-29a/b, KO: $15.67 \pm 1.302, p=0.0811, n=9$ ). (D) GnRH challenge in miR-29a/b, KO and wild-type mice (wild-type: $3.19 \pm 0.48 \mathrm{mlU} / \mathrm{ml}, \mathrm{miR}-29 \mathrm{a} / \mathrm{b}_{1} \mathrm{KO}: 2.255 \pm 0.1287 \mathrm{mlU} / \mathrm{ml}, \mathrm{p}=0.0376, \mathrm{n}=5 ; \mathrm{GnRH}:$ wild-type: $4.857 \pm 0.2346 \mathrm{mlU} / \mathrm{ml}, p=0.0138, \mathrm{n}=6, \mathrm{miR}-29 \mathrm{a} / \mathrm{b}_{1} \mathrm{KO}: 3.484 \pm$ $0.3357 \mathrm{mlU} / \mathrm{ml}, p=0.0145, \mathrm{n}=7) .{ }^{*} p<0.05,{ }^{* *} p<0.01$ and ${ }^{* \star * *} p<0.0001$.

identified in this study were found to be involved in a wide range of biological process, and most of the differential proteins were classified in the protein transport processes, which are essential for vesicle-mediated transport in the cytoplasm and exocytosis during plasma infusion (40-42) (Figure 7D).

The intersected gene between upregulated expression and miR-29a targets through miRDB (http://mirdb.org) were analyzed, 11 potential direct target transcripts of miR-29a were discovered (Figure 7E), and predicted target genes were expected to be upregulated in miRNA loss of-function models (Figure 7G). Among them, collagen family Col1a1, Col4a2 and Col5a1 are target genes of miR-29a-3p, and promote cancer cells invasion and migration (43-45). In addition, miR-29a can promote the neurite outgrowth by targeting extracellular matrix-related genes like Fibrillin 1 (Fbn1) and hyaluronan and proteoglycan link protein 1 (Hapln1) $(46,47)$, which dramatically increased in the pituitary of $m i R-29 a / b_{1} \mathrm{KO}$ mice. Hdac4 (48), which is key epigenetic modified writer, may play important roles in the change of gene expression pattern in $m i R$ $29 a / b_{1}$ gene knockout mice, especially for down-regulated genes. For the 88 down-regulated proteins in the pituitary of $m i R$ $29 a / b_{1}$ KO mice, a considerable portion of them participate in vesicle-mediated transport and secretion (Ergic1, Fkbp2, Ssr3, Stat5a, Crhbp, Figure 7F). Notably, Ergic1, encodes a cycling membrane protein, and plays an important role in transport between endoplasmic reticulum and Golgi (49). Absence of
trAp $\gamma$ (SSr3) impairs protein translocation into the endoplasmic reticulum and affects transport (50). Myosins were reported as core players in the final stages of regulated secretory pathways (51). Treatment of pituitary cells with the myosin light chain (Myl2/3) kinase inhibitor, wortmannin, attenuated $\mathrm{GnRH}$-induced $\mathrm{LH}$ release (52). Further validated by quantitative PCR (qPCR) that the mRNA transcripts of these genes, which were consistent with LC-MS/MS (Figure 7G). These results indicated the deficiency of $m i R-29 a / b_{1}$ blocked proteins transportation, leading to impaired pituitary hormone secretion, especially LH released.

\section{DISCUSSION}

A lack of $m i R-29 a / b_{1}$ leads to female sterility in mice, which has been mentioned previously (1); however, the mechanisms underlying this result were not published or illustrated. In this work, we demonstrated that low serum LH level and ovulation disorder might be the direct cause of subfertility in female $m i R$ $29 a / b_{1}$ KO mice. This conclusion is further proved by the results that oocyte development is normal in the ovaries of mutant mice and normal eggs could be obtained through super-ovulated. Compared to wild-type mice, the pituitary gland in mutant mice stimulated with the same concentration of $\mathrm{GnRH}$ produced reduction $\mathrm{LH}$ secreted into the blood, indicating that 
A
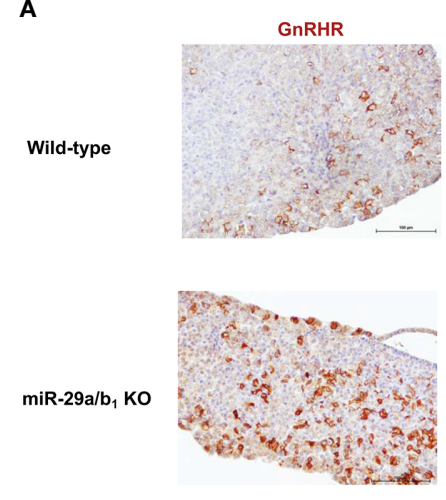

B
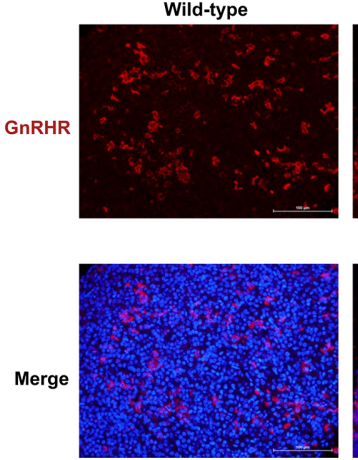

miR-29a/b $b_{1}$ ko
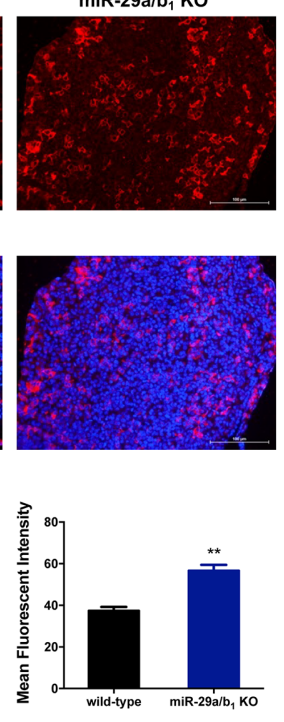

Negative Control
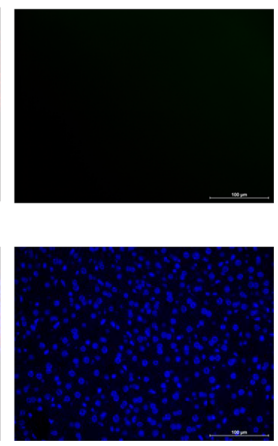
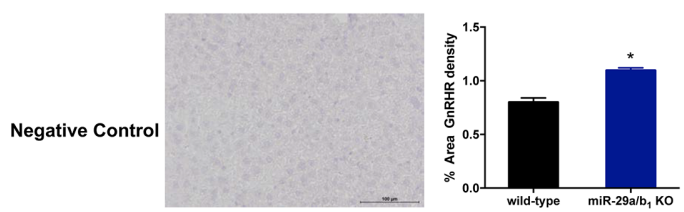

D

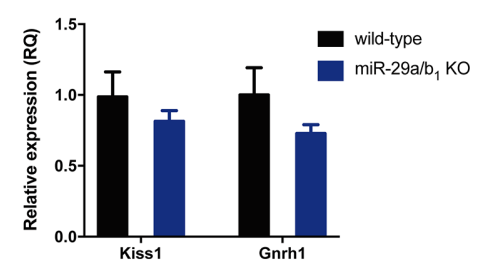

E
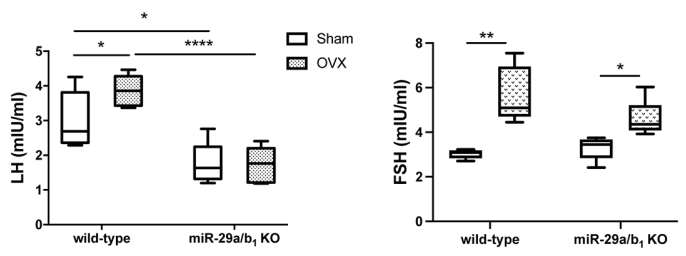

$\square$ Sham

tavx
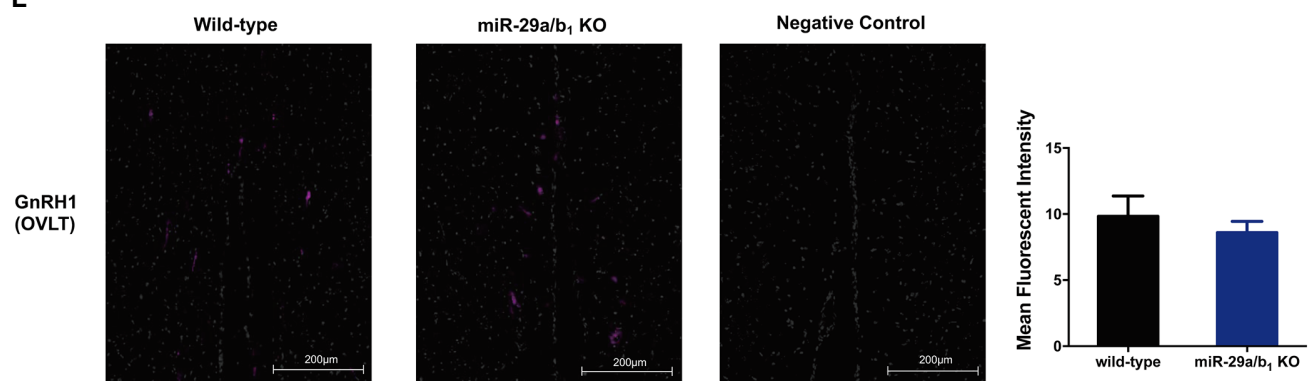

FIGURE 5 | Central mechanism in miR-29a/b, KO mice. (A, B) GnRHR immunoreactivity in pituitary of wild-type and miR-29a/b, KO females. The receptor was not detectable on the plasma membrane of control. (immunohistochemical: wild-type: $13.43 \pm 0.7927$, miR-29a/b 1 KO: $25.47 \pm 0.534, p=0.0249$; immunofluorescence: wild-type: $37.79 \pm 1.858$, miR-29a/b, KO: $56.64 \pm 2.767, p=0.0045, n=3)$. (C) Serum LH and FSH levels in miR-29a/b, KO females and controls following ovariectomy (OVX) and sham-operated controls (Sham). (LH: wild-type: $p=0.0401$, miR-29a/b, KO: $p=0.9249$; FSH: wild-type: $p=0.0016$, miR-29a/b, KO: $p=0.0185, \mathrm{n}=6$ ). (D) Expression of Kiss1 and Gnrh1 in hypothalamus (Gnrh1: wild-type: $1 \pm 0.1912$, miR-29a/b, KO: $0.7287 \pm 0.06234, p=0.1874$, Kiss1: wild-type: $1 \pm 0.1305$, miR-29a/b, KO: $0.8142 \pm 0.0757, p=0.8405, \mathrm{n}=15$ ). (E) Normal distribution of $\mathrm{GnRH}$ neurons in miR-29a/b, $\mathrm{KO}$ mice compared to control littermates.

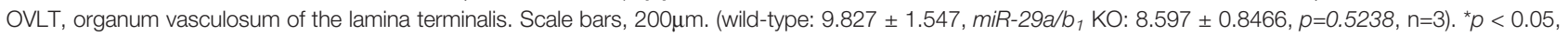
${ }^{* \star} p<0.01$ and ${ }^{* \star *} p<0.0001$.

miR-29a/b 1 KO females maintained normal pituitary responsiveness to $\mathrm{GnRH}$, although expression of GnRHR was higher in $m i R-29 a / b_{1} \mathrm{KO}$ females pituitaries which may represent compensation for plasma LH insufficiency (53). Meanwhile the expression of LH protein was higher in mutant pituitaries than that in wild types. This suggests that knockout of
miR-29a/ $b_{1}$ results in deficits in $\mathrm{LH}$ secretion from the pituitary but not in LH synthesis stimulated by $\operatorname{GnRH}(54,55)$. Proteomic analysis of the pituitary showed that a large number of proteins related to cellular vesicle-mediated secretion and protein transport were significantly changed in $m i R-29 a / b_{1} \mathrm{KO}$ mice. This effect seems to be omnidirectional, from the vesicle 

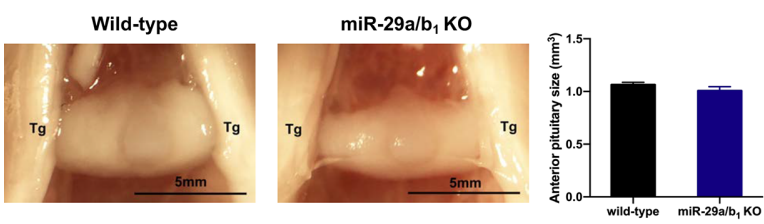

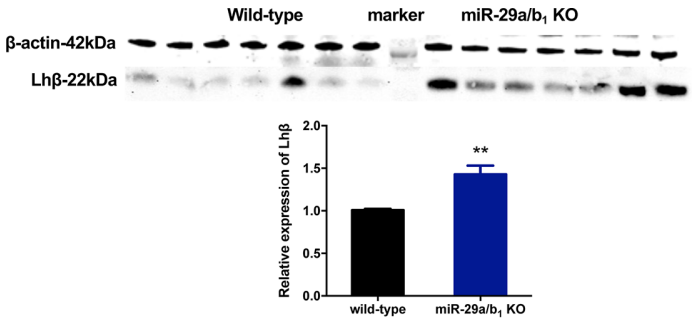

D

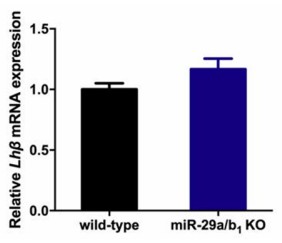

E

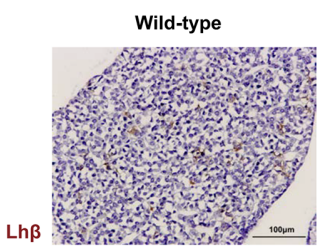

Negative Control

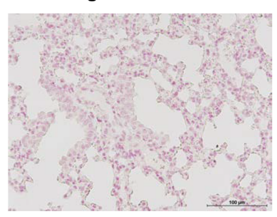

$\mathbf{F}$

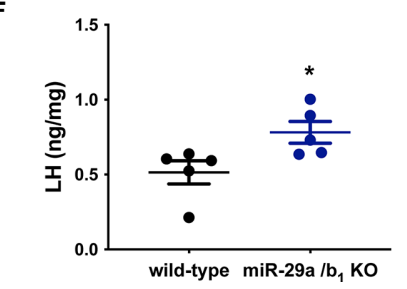

$\mathrm{miR}-29 \mathrm{a} / \mathrm{b}_{1}$ KO
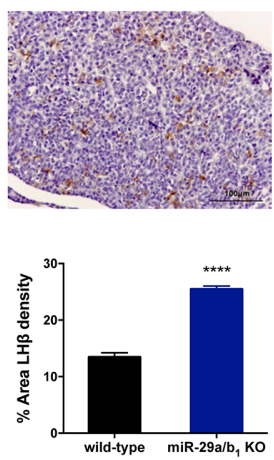

Wild-type

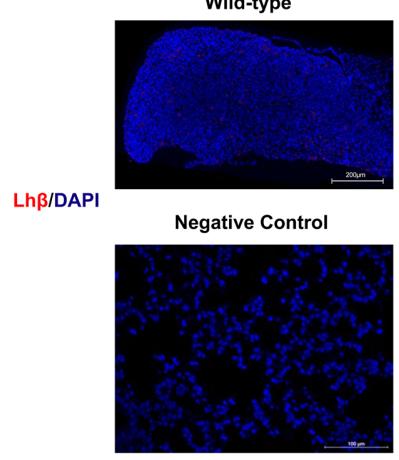

miR-29a/b 1 KO
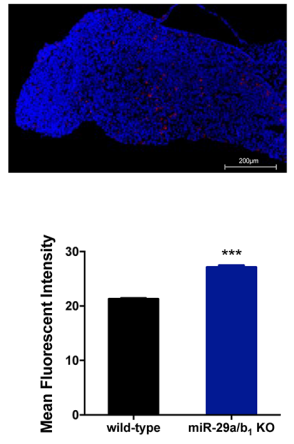

FIGURE 6 | Impairment of Lh $\beta$ protein export in the pituitary as a deficiency of miR-29a/ $b_{1}$. (A) Pituitary from female wild-type mice $(n=9)$ and miR-29a/b, $K O$ mice $(n=5)$ were photographed in situ during dissection. Trigeminal nerves that flank the pituitary are marked as Tg. Scale bar $=5 \mathrm{~mm}(2 \mathrm{x}$ magnification). Anterior pituitary size was statistically analyzed $(p=0.2411, n=7)$. (B) The entire sagittal pituitary and higher magnification in the box from wild-type and miR-29a/b, $\mathrm{KO}$ females are shown. (C, D) $L H \beta$ protein $(p=0.0019)$ and transcripts $(p=0.1278)$ levels were determined in pituitary tissues from miR-29a/ $b$, $K O$ and wild-type mice $(n=7)$. (E) Quantification of immunoreactivity LH $\beta$ in pituitary of miR-29a/b, KO or control mice (immunohistochemical: wild-type:13.43 $\pm 0.7927, n=5, m i R-29 a / b, K O$ : $25.47 \pm 0.534, \mathrm{n}=4, p<0.0001$; immunofluorescence: wild-type: $21.27 \pm 0.147$, miR-29a/b, KO: $27.11 \pm 0.3642, p=0.0001, \mathrm{n}=3$ ). LH $\beta$ was not detectable on the plasma membrane of control. Scale bars: $200 \mu \mathrm{m}$. Red indicates positive-LH cells, Cell nuclei (blue) were stained with haematoxylin or DAPI. (F) LH proteins relative contents in females. (Wild-type: $0.5147 \pm 0.07769$, miR-29a/b, KO: $0.7819 \pm 0.07199, p=0.0357, \mathrm{n}=5) .{ }^{*} p<0.05,{ }^{* *} p<0.01,{ }^{* \star *} p<0.001$ and ${ }^{* \star \star *} p<0.0001$.

transport between endoplasmic reticulum and Golgi apparatus, as well as the process of docking and priming of secretory vesicle on the cell membrane. As a result, many kinds of secretory proteins, including LH $\beta$, were accumulated in pituitary cells. These secreted proteins accounted for $44 \%$ of the upregulated proteins in the pituitary of mutant mice.
It is worth noting that $\mathrm{FSH}$ required for follicle growth and development and maturation of the ovum (56-58) was less affected by the knockout of $m i R-29 a / b_{1}$. Different secretion modes between FSH and LH might be an important reason $(59,60)$. LH is secreted via a regulated pathway, while FSH release is primarily constitutive and controlled by synthesis. Increased FSH protein level in the 


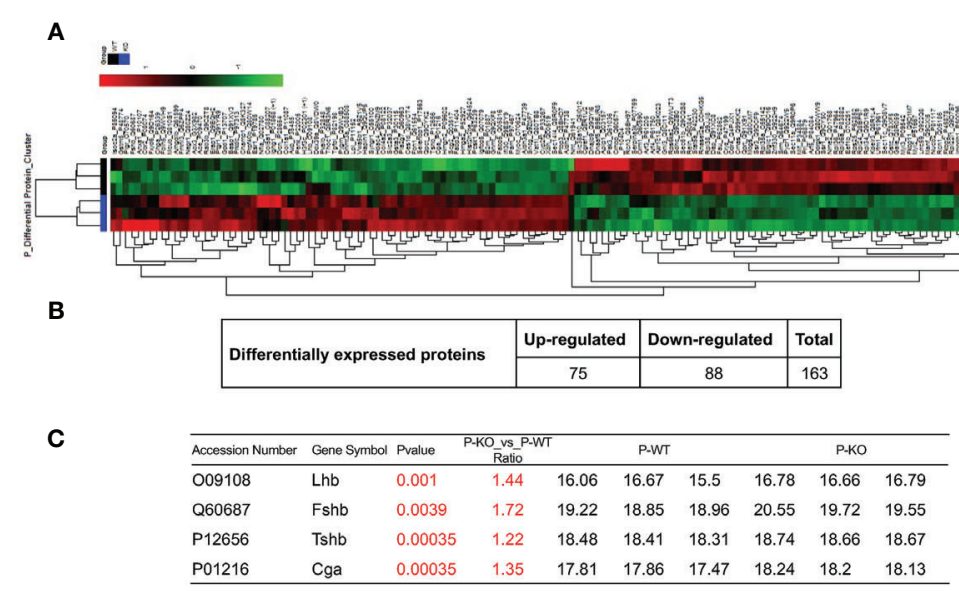

。

E
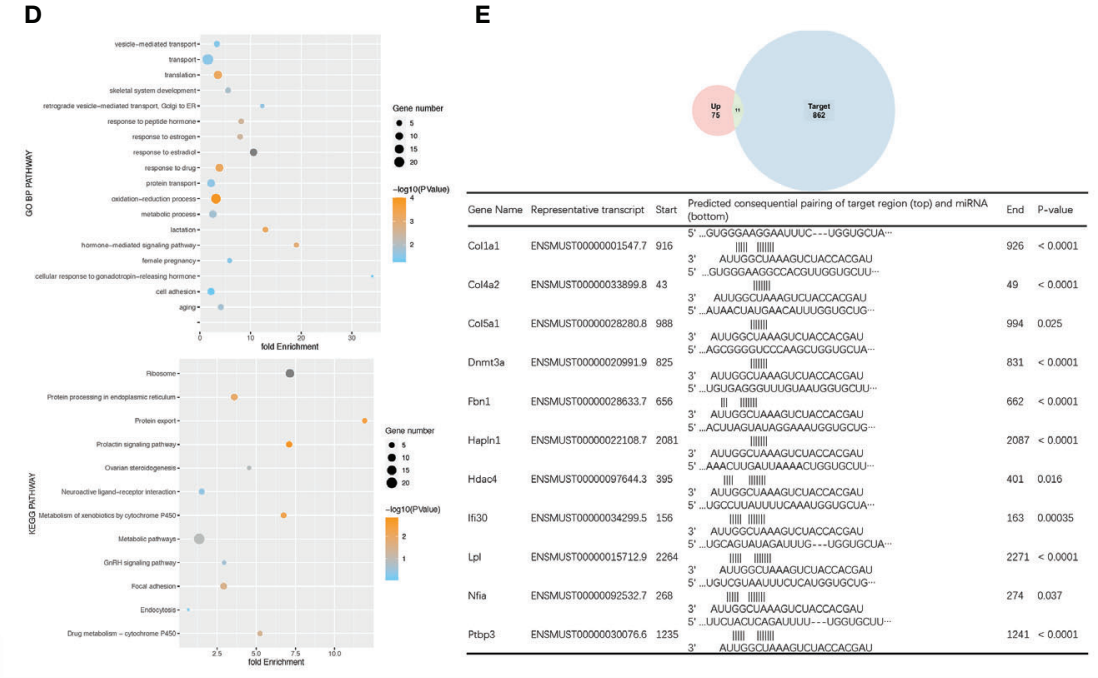

F

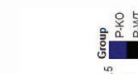

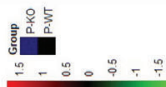

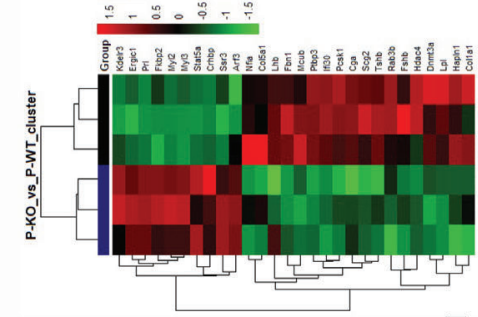

G

wild-type

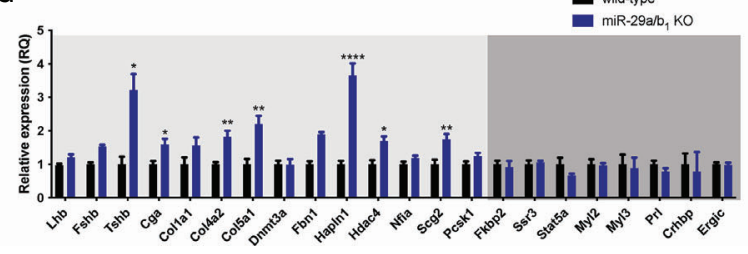

FIGURE 7 | Comparing protein expression profile in the pituitary of wild-type and miR-29a/b, KO mice. (A, B) Differential protein from pituitary of miR-29a/b, KO and wild-type mice ( $\mathrm{n}=3$ for each) detected by MS. (C) Pituitary hormone expression. (D) GO and KEGG analysis of the pituitary from miR-29a/b, KO compared to wild-type mice. (E) 11 predicted miR-29a targets from up-regulated proteins. (F) Heat map of genes about vesicle-transport. (G) Quantification of up-regulation genes including coded pituitary hormone (light gray shaded area) and down-regulation vesicle-transport activators (dark gray shaded area) (Lhb: $p=0.2411, F s h b$ : $p=0.0002$, Tshb: $p=0.0017$, Cga: $p=0.0117$, Col1a1: $p=0.1038$, Col4a2: $p=0.0012$, Col5a1: $p=0.0023$, Dnmt3a: $p=0.9237$, Fbn1: $p<0.0001$, Hpln1: $p<0.0001$, Hdac4: $p=0.0332$, Nfia: $p=0.1379$, Scg2: $p=0.0058$, Pcsk1: $p=0.0743$, Fkbp2: $p=0.6975$, Ssr3: $p=0.6844$, Stat5a:0.1329, Myl2: $p=0.7879$, Myl3: $p=0.7858$, Prl: $p=0.1706$, Crhbp: $p=0.7510$, Ergic: $p=0.7937, n=6) .{ }^{*} p<0.05,{ }^{* *} p<0.01$ and ${ }^{* \star \star *} p<0.0001$. 
TABLE 2 | Differentially expressed proteins in pituitary involved in miR-29 regulation and protein transport ( $p<0.05$ and fold change $\geq 1.2$ or $\leq 0.83)$.

\begin{tabular}{|c|c|c|c|c|c|}
\hline $\begin{array}{l}\text { Accession } \\
\text { Number }\end{array}$ & $\begin{array}{l}\text { Gene } \\
\text { Symbol }\end{array}$ & Identified Proteins & $\begin{array}{l}\text { Molecular } \\
\text { Weight }\end{array}$ & $P$ value & $\begin{array}{l}\text { Ratio (KO vs wild- } \\
\text { type) }\end{array}$ \\
\hline Q60687 & Fshb & Follitropin subunit beta OS=Mus musculus $\mathrm{GN}=$ Fshb $P E=2 \mathrm{SV}=1$ & $15 \mathrm{kDa}$ & 0.0039 & 1.72 \\
\hline P32848 & Pvalb & Parvalbumin alpha OS=Mus musculus GN=Pvalb PE=1 SV=3 & $12 \mathrm{kDa}$ & 0.0065 & 1.65 \\
\hline Q9ZOF7 & Sncg & Gamma-synuclein OS=Mus musculus GN=Sncg PE=1 SV=1 & $13 \mathrm{kDa}$ & $\begin{array}{c}< \\
0.0001\end{array}$ & 1.55 \\
\hline P01887 & B2m & Beta-2-microglobulin OS=Mus musculus GN=B2m PE=1 SV=2 & $14 \mathrm{kDa}$ & 0.0039 & 1.54 \\
\hline Q80TB8 & Vat11 & $\begin{array}{l}\text { Synaptic vesicle membrane protein VAT- } 1 \text { homolog-like } O S=\text { Mus musculus } G N=V a t 11 \\
P E=1 S V=2\end{array}$ & $46 \mathrm{kDa}$ & $\begin{array}{c}< \\
0.0001\end{array}$ & 1.48 \\
\hline Q03517 & Scg2 & Secretogranin-2 OS=Mus musculus GN=Scg2 PE=1 SV=1 & $71 \mathrm{kDa}$ & $\begin{array}{c}< \\
0.0001\end{array}$ & 1.47 \\
\hline 009108 & Lhb & Lutropin subunit beta OS=Mus musculus GN=Lhb PE=2 SV=2 & $15 \mathrm{kDa}$ & 0.001 & 1.44 \\
\hline Q9CYK2 & Qpct & Glutaminyl-peptide cyclotransferase OS=Mus musculus GN=Qpct PE=1 SV=2 & $41 \mathrm{kDa}$ & $\begin{array}{c}< \\
0.0001\end{array}$ & 1.44 \\
\hline Q9ESY9 & Ifi30 & $\begin{array}{l}\text { Gamma-interferon-inducible lysosomal thiol reductase OS=Mus musculus } G N=\mid \text { fi30 } \\
P E=1 S V=3\end{array}$ & $28 \mathrm{kDa}$ & 0.00035 & 1.41 \\
\hline Q60963 & Pla2g7 & Platelet-activating factor acetylhydrolase OS=Mus musculus GN=Pla2g7 PE=2 SV=2 & $49 \mathrm{kDa}$ & $\begin{array}{c}< \\
0.0001\end{array}$ & 1.40 \\
\hline O70570 & Pigr & Polymeric immunoglobulin receptor $\mathrm{OS}=$ Mus musculus $\mathrm{GN}=$ Pigr $\mathrm{PE}=1 \mathrm{SV}=1$ & $85 \mathrm{kDa}$ & 0.037 & 1.38 \\
\hline P33267 & Cyp2f2 & Cytochrome P450 2F2 OS=Mus musculus GN=Cyp2f2 PE=1 SV=1 & $56 \mathrm{kDa}$ & $\begin{array}{c}< \\
0.0001\end{array}$ & 1.37 \\
\hline Q8R3N6 & Thoc1 & THO complex subunit $1 \mathrm{OS}=$ Mus musculus $\mathrm{GN}=$ Thoc1 $\mathrm{PE}=1 \mathrm{SV}=1$ & $75 \mathrm{kDa}$ & 0.025 & 1.37 \\
\hline P01216 & Cga & Glycoprotein hormones alpha chain OS=Mus musculus GN=Cga PE=2 SV=1 & $14 \mathrm{kDa}$ & 0.00035 & 1.35 \\
\hline P32037 & Slc2a3 & $\begin{array}{l}\text { Solute carrier family } 2 \text {, facilitated glucose transporter member } 3 \mathrm{OS}=\text { Mus musculus } \\
\mathrm{GN}=\mathrm{Slc} 2 \mathrm{a} 3 \mathrm{PE}=1 \mathrm{SV}=1\end{array}$ & $53 \mathrm{kDa}$ & $\begin{array}{c}< \\
0.0001\end{array}$ & 1.35 \\
\hline Q8VCT4 & Ces1d & Carboxylesterase 1D OS=Mus musculus GN=Ces1d PE=1 SV=1 & $62 \mathrm{kDa}$ & $\begin{array}{c}< \\
0.0001\end{array}$ & 1.34 \\
\hline P30115 & Gsta3 & Glutathione S-transferase A3 OS=Mus musculus GN=Gsta3 PE=1 SV=2 & $25 \mathrm{kDa}$ & 0.0039 & 1.34 \\
\hline P08122 & Col4a2 & Collagen alpha-2(IV) chain OS=Mus musculus $\mathrm{GN}=\mathrm{Col} 4 \mathrm{a} 2 \mathrm{PE}=1 \mathrm{SV}=4$ & $167 \mathrm{kDa}$ & $\begin{array}{c}< \\
0.0001\end{array}$ & 1.33 \\
\hline P52927 & Hmga2 & $\begin{array}{l}\text { High mobility group protein HMGI-C OS=Mus musculus GN=Hmga2 } P E=1 \\
\mathrm{SV}=1\end{array}$ & $12 \mathrm{kDa}$ & 0.00035 & 1.33 \\
\hline O55100 & Syngr1 & Synaptogyrin-1 OS=Mus musculus GN=Syngr1 PE=1 SV=2 & $26 \mathrm{kDa}$ & 0.0039 & 1.33 \\
\hline Q64524 & Hist2h2be & Histone H2B type 2-E OS=Mus musculus GN=Hist2h2be PE=1 SV=3 & $14 \mathrm{kDa}$ & 0.0039 & 1.32 \\
\hline Q9QXF8 & Gnmt & Glycine N-methyltransferase OS=Mus musculus GN=Gnmt PE=1 SV=3 & $33 \mathrm{kDa}$ & 0.0039 & 1.32 \\
\hline Q8VDW0 & Ddx39a & ATP-dependent RNA helicase DDX39A OS=Mus musculus GN=Ddx39a PE=1 SV=1 & $49 \mathrm{kDa}$ & 0.016 & 1.32 \\
\hline A9Z1V5 & Vwa5b1 & $\begin{array}{l}\text { von Willebrand factor A domain-containing protein 5B1 OS=Mus musculus } \\
\mathrm{GN}=\mathrm{Vwa5b1} \mathrm{PE}=2 \mathrm{SV}=1\end{array}$ & $134 \mathrm{kDa}$ & 0.0039 & 1.32 \\
\hline Q6NZM9 & Hdac4 & Histone deacetylase 4 OS=Mus musculus GN=Hdac4 PE=1 SV=1 & 119 kDa & 0.016 & 1.32 \\
\hline G3X982 & Aox3 & Aldehyde oxidase $3 \mathrm{OS}=$ Mus musculus $\mathrm{GN}=\mathrm{Aox} 3 \mathrm{PE}=1 \mathrm{SV}=1$ & $147 \mathrm{kDa}$ & 0.0065 & 1.32 \\
\hline P47739 & Aldh3a1 & $\begin{array}{l}\text { Aldehyde dehydrogenase, dimeric NADP-preferring } O S=\text { Mus musculus } G N=A l d h 3 a 1 \\
P E=1 S V=2\end{array}$ & $50 \mathrm{kDa}$ & $\begin{array}{c}< \\
0.0001\end{array}$ & 1.31 \\
\hline Q9D164 & Fxyd6 & $\begin{array}{l}\text { FXYD domain-containing ion transport regulator } 6 \text { OS=Mus musculus GN=Fxyd6 } \\
P E=1 S V=2\end{array}$ & $10 \mathrm{kDa}$ & 0.0065 & 1.31 \\
\hline Q9EQH2 & Erap1 & Endoplasmic reticulum aminopeptidase $1 \mathrm{OS}=$ Mus musculus $\mathrm{GN}=\mathrm{Erap} 1 \mathrm{PE}=1 \mathrm{SV}=2$ & 107 kDa & $\begin{array}{c}< \\
0.0001\end{array}$ & 1.30 \\
\hline P01868 (+1) & lghg1 & Ig gamma- 1 chain $\mathrm{C}$ region secreted form $\mathrm{OS}=$ Mus musculus $\mathrm{GN}=\operatorname{lghg} 1 \mathrm{PE}=1 \mathrm{SV}=1$ & $36 \mathrm{kDa}$ & 0.00035 & 1.30 \\
\hline Q9QUP5 & Hapln1 & $\begin{array}{l}\text { Hyaluronan and proteoglycan link protein } 1 \mathrm{OS}=\text { Mus musculus } \mathrm{GN}=\mathrm{Hapln} 1 \mathrm{PE}=1 \\
\mathrm{SV}=1\end{array}$ & $40 \mathrm{kDa}$ & $\begin{array}{c}< \\
0.0001\end{array}$ & 1.29 \\
\hline 088508 & Dnmt3a & $\begin{array}{l}\text { DNA (cytosine-5)-methyltransferase } 3 A \text { OS=Mus musculus } G N=D n m t 3 a ~ P E=1 \\
S V=2\end{array}$ & $102 \mathrm{kDa}$ & $\begin{array}{c}< \\
0.0001\end{array}$ & 1.29 \\
\hline Q07079 & lgfbp5 & Insulin-like growth factor-binding protein 5 OS=Mus musculus GN=lgfbp5 PE=1 SV=1 & $30 \mathrm{kDa}$ & $\begin{array}{c}< \\
0.0001\end{array}$ & 1.28 \\
\hline P26339 & Chga & Chromogranin-A OS=Mus musculus GN=Chga $P E=1 \mathrm{SV}=1$ & $52 \mathrm{kDa}$ & $\begin{array}{c}< \\
0.0001\end{array}$ & 1.27 \\
\hline P09602 & Hmgn2 & $\begin{array}{l}\text { Non-histone chromosomal protein HMG-17 OS=Mus musculus GN=Hmgn2 PE=1 } \\
\mathrm{SV}=2\end{array}$ & $9 \mathrm{kDa}$ & $\begin{array}{c}< \\
0.0001\end{array}$ & 1.27 \\
\hline Q9CZT8 & Rab3b & Ras-related protein Rab-3B OS=Mus musculus GN=Rab3b PE=1 SV=1 & $25 \mathrm{kDa}$ & $\begin{array}{c}< \\
0.0001\end{array}$ & 1.27 \\
\hline P28654 & Dcn & Decorin $O S=$ Mus musculus $\mathrm{GN}=\mathrm{Dcn} \mathrm{PE}=1 \mathrm{SV}=1$ & $40 \mathrm{kDa}$ & $\begin{array}{c}< \\
0.0001\end{array}$ & 1.27 \\
\hline P85094 & Isoc2a & $\begin{array}{l}\text { Isochorismatase domain-containing protein } 2 \mathrm{~A} O \mathrm{OS}=\mathrm{Mus} \text { musculus } \mathrm{GN}=\mathrm{IsOc} 2 \mathrm{a} \mathrm{PE}=1 \\
\mathrm{SV}=1\end{array}$ & $22 \mathrm{kDa}$ & 0.0027 & 1.27 \\
\hline P22005 & Penk & Proenkephalin-A OS=Mus musculus GN=Penk PE=1 SV=2 & $31 \mathrm{kDa}$ & 0.01 & 1.27 \\
\hline
\end{tabular}


TABLE 2 | Continued

\begin{tabular}{|c|c|c|c|c|c|}
\hline $\begin{array}{l}\text { Accession } \\
\text { Number }\end{array}$ & $\begin{array}{l}\text { Gene } \\
\text { Symbol }\end{array}$ & Identified Proteins & $\begin{array}{l}\text { Molecular } \\
\text { Weight }\end{array}$ & $\mathbf{P}$ value & $\begin{array}{l}\text { Ratio (KO vs wild- } \\
\text { type) }\end{array}$ \\
\hline P02301 (+1) & $\mathrm{H} 3 \mathrm{f} 3 \mathrm{c}$ & Histone H3.3C OS=Mus musculus GN=H3f3c PE=3 SV=3 & $15 \mathrm{kDa}$ & 0.0039 & 1.27 \\
\hline Q91XV3 & Basp1 & Brain acid soluble protein $1 \mathrm{OS}=$ Mus musculus $\mathrm{GN}=\mathrm{Basp} 1 \mathrm{PE}=1 \mathrm{SV}=3$ & $22 \mathrm{kDa}$ & $\begin{array}{c}< \\
0.0001\end{array}$ & 1.27 \\
\hline Q02780 & Nfia & Nuclear factor 1 A-type $O S=$ Mus musculus $\mathrm{GN}=\mathrm{Nfia} \mathrm{PE}=1 \mathrm{SV}=1$ & 59 kDa & 0.037 & 1.27 \\
\hline Q8K327 & Champ1 & $\begin{array}{l}\text { Chromosome alignment-maintaining phosphoprotein } 1 \mathrm{OS}=\text { Mus musculus } \\
\mathrm{GN}=\text { Champ1 } \mathrm{PE}=1 \mathrm{SV}=1\end{array}$ & $88 \mathrm{kDa}$ & 0.0017 & 1.27 \\
\hline Q6ZPF4 & Fmnl3 & Formin-like protein 3 OS=Mus musculus $\mathrm{GN}=\mathrm{Fmnl3} \mathrm{PE}=1 \mathrm{SV}=2$ & $117 \mathrm{kDa}$ & 0.037 & 1.27 \\
\hline P82198 & Tgfbi & $\begin{array}{l}\text { Transforming growth factor-beta-induced protein ig-h3 OS=Mus musculus GN=Tgfbi } \\
\mathrm{PE}=1 \mathrm{SV}=1\end{array}$ & $75 \mathrm{kDa}$ & $\begin{array}{c}< \\
0.0001\end{array}$ & 1.26 \\
\hline Q61599 & Arhgdib & Rho GDP-dissociation inhibitor 2 OS=Mus musculus GN=Arhgdib PE=1 SV=3 & $23 \mathrm{kDa}$ & 0.00034 & 1.26 \\
\hline Q80W14 & Prpf40b & $\begin{array}{l}\text { Pre-mRNA-processing factor } 40 \text { homolog B OS=Mus musculus GN=Prpf } 40 \mathrm{~b} \text { PE=1 } \\
\mathrm{SV}=2\end{array}$ & $99 \mathrm{kDa}$ & 0.0039 & 1.26 \\
\hline P97467 & Pam & $\begin{array}{l}\text { Peptidyl-glycine alpha-amidating monooxygenase } O S=\text { Mus musculus } G N=P a m P E=1 \\
S V=2\end{array}$ & $109 \mathrm{kDa}$ & $\begin{array}{c}< \\
0.0001\end{array}$ & 1.25 \\
\hline P11152 & Lpl & Lipoprotein lipase OS=Mus musculus $\mathrm{GN}=\mathrm{Lpl} \mathrm{PE}=1 \mathrm{SV}=3$ & 53 kDa & $\begin{array}{c}< \\
0.0001\end{array}$ & 1.25 \\
\hline Q00519 & Xdh & Xanthine dehydrogenase/oxidase OS=Mus musculus $\mathrm{GN}=\mathrm{Xdh} P E=1 \mathrm{SV}=5$ & $147 \mathrm{kDa}$ & 0.024 & 1.25 \\
\hline Q91YR9 & Ptgr1 & Prostaglandin reductase $1 \mathrm{OS}=$ Mus musculus $\mathrm{GN}=\mathrm{Ptg} 1 \mathrm{PE}=1 \mathrm{SV}=2$ & $36 \mathrm{kDa}$ & 0.0013 & 1.25 \\
\hline P11087 & Col1a1 & Collagen alpha-1(I) chain OS=Mus musculus $\mathrm{GN}=$ Col1a1 $\mathrm{PE}=1 \mathrm{SV}=4$ & 138 kDa & $\begin{array}{c}< \\
0.0001\end{array}$ & 1.24 \\
\hline P10107 & Anxa1 & Annexin $\mathrm{A} 1 \mathrm{OS}=\mathrm{Mus}$ musculus $\mathrm{GN}=\mathrm{Anxa1} \mathrm{PE}=1 \mathrm{SV}=2$ & $39 \mathrm{kDa}$ & $\begin{array}{c}< \\
0.0001\end{array}$ & 1.24 \\
\hline P13707 & Gpd1 & $\begin{array}{l}\text { Glycerol-3-phosphate dehydrogenase }[\mathrm{NAD}(+)] \text {, cytoplasmic OS=Mus musculus } \\
\mathrm{GN}=\mathrm{Gpd} 1 \mathrm{PE}=1 \mathrm{SV}=3\end{array}$ & $38 \mathrm{kDa}$ & $\begin{array}{c}< \\
0.0001\end{array}$ & 1.24 \\
\hline 088207 & Col5a1 & Collagen alpha-1(V) chain OS=Mus musculus GN=Col5a1 PE=1 SV=2 & $184 \mathrm{kDa}$ & 0.025 & 1.24 \\
\hline Q61554 & Fbn1 & Fibrillin-1 OS=Mus musculus $\mathrm{GN}=\mathrm{Fbn} 1 \mathrm{PE}=1 \mathrm{SV}=2$ & 312 kDa & $\begin{array}{c}< \\
0.0001\end{array}$ & 1.23 \\
\hline Q05816 & Fabp5 & Fatty acid-binding protein, epidermal OS=Mus musculus GN=Fabp5 PE=1 SV=3 & $15 \mathrm{kDa}$ & $\begin{array}{c}< \\
0.0001\end{array}$ & 1.23 \\
\hline P08074 & Cbr2 & Carbonyl reductase [NADPH] 2 OS=Mus musculus GN=Cbr2 PE=1 SV=1 & $26 \mathrm{kDa}$ & 0.0013 & 1.23 \\
\hline P97313 & Prkdc & $\begin{array}{l}\text { DNA-dependent protein kinase catalytic subunit } O S=\text { Mus musculus } G N=P r k d c ~ P E=1 \\
S V=3\end{array}$ & $471 \mathrm{kDa}$ & 0.031 & 1.23 \\
\hline P19785 & Esr1 & Estrogen receptor $\mathrm{OS}=$ Mus musculus $\mathrm{GN}=\mathrm{Esr} 1 \mathrm{PE}=1 \mathrm{SV}=1$ & $67 \mathrm{kDa}$ & 0.0031 & 1.23 \\
\hline P63239 & Pcsk1 & Neuroendocrine convertase $1 \mathrm{OS}=$ Mus musculus GN=Pcsk1 PE=1 SV=1 & $84 \mathrm{kDa}$ & $\begin{array}{c}< \\
0.0001\end{array}$ & 1.22 \\
\hline Q8BHD7 & Ptbp3 & $\begin{array}{l}\text { Polypyrimidine tract-binding protein } 3 \text { OS=Mus musculus GN=Ptbp3 PE=1 } \\
\mathrm{SV}=1\end{array}$ & 57 kDa & $\begin{array}{c}< \\
0.0001\end{array}$ & 1.22 \\
\hline Q9WUB3 & Pygm & Glycogen phosphorylase, muscle form OS=Mus musculus GN=Pygm PE=1 SV=3 & $97 \mathrm{kDa}$ & $\begin{array}{c}< \\
0.0001\end{array}$ & 1.22 \\
\hline P12656 & Tshb & Thyrotropin subunit beta OS=Mus musculus GN=Tshb PE=2 SV=1 & $15 \mathrm{kDa}$ & 0.00035 & 1.22 \\
\hline Q9WVH9 & Fbln5 & Fibulin-5 OS=Mus musculus GN=Fbln5 PE=1 SV=1 & $50 \mathrm{kDa}$ & 0.016 & 1.22 \\
\hline P35455 & Avp & Vasopressin-neurophysin 2-copeptin OS=Mus musculus GN=Avp PE=2 SV=1 & $18 \mathrm{kDa}$ & $\begin{array}{c}< \\
0.0001\end{array}$ & 1.21 \\
\hline O70624 & Myoc & Myocilin OS=Mus musculus $\mathrm{GN}=\mathrm{Myoc} \mathrm{PE}=1 \mathrm{SV}=1$ & $55 \mathrm{kDa}$ & $\begin{array}{c}< \\
0.0001\end{array}$ & 1.21 \\
\hline P09470 & Ace & Angiotensin-converting enzyme OS=Mus musculus GN=Ace PE=1 SV=3 & $151 \mathrm{kDa}$ & 0.0006 & 1.21 \\
\hline P11404 & Fabp3 & Fatty acid-binding protein, heart OS=Mus musculus $\mathrm{GN}=\mathrm{Fabp} 3 \mathrm{PE}=1 \mathrm{SV}=5$ & $15 \mathrm{kDa}$ & $\begin{array}{c}< \\
0.0001\end{array}$ & 1.21 \\
\hline Q80Z24 & Negr1 & Neuronal growth regulator $1 \mathrm{OS}=$ Mus musculus $\mathrm{GN}=$ Negr1 $\mathrm{PE}=1 \mathrm{SV}=1$ & $38 \mathrm{kDa}$ & 0.01 & 1.21 \\
\hline P47738 & Aldh2 & Aldehyde dehydrogenase, mitochondrial OS=Mus musculus GN=Aldh2 PE=1 SV=1 & $57 \mathrm{kDa}$ & $\begin{array}{c}< \\
0.0001\end{array}$ & 1.21 \\
\hline P17563 & Selenbp1 & Selenium-binding protein $1 \mathrm{OS}=$ Mus musculus $\mathrm{GN}=$ Selenbp1 $\mathrm{PE}=1 \mathrm{SV}=2$ & $53 \mathrm{kDa}$ & $\begin{array}{c}< \\
0.0001\end{array}$ & 1.21 \\
\hline P48774 & Gstm5 & Glutathione S-transferase Mu 5 OS=Mus musculus GN=Gstm5 PE=1 SV=1 & $27 \mathrm{kDa}$ & $\begin{array}{c}< \\
0.0001\end{array}$ & 1.21 \\
\hline Q8R0F9 & $\operatorname{Sec} 1414$ & SEC14-like protein 4 OS=Mus musculus $\mathrm{GN}=\mathrm{Sec} 1414 \mathrm{PE}=1 \mathrm{SV}=1$ & $46 \mathrm{kDa}$ & $\begin{array}{c}< \\
0.0001\end{array}$ & 1.21 \\
\hline Q810S1 & Mcub & $\begin{array}{l}\text { Calcium uniporter regulatory subunit MCUb, mitochondrial } O S=\text { Mus musculus } \\
\text { GN=Mcub } P E=1 S V=1\end{array}$ & $40 \mathrm{kDa}$ & 0.00034 & 1.21 \\
\hline P81117 & Nucb2 & Nucleobindin-2 OS=Mus musculus GN=Nucb2 PE=1 SV=2 & $50 \mathrm{kDa}$ & $\begin{array}{c}< \\
0.0001\end{array}$ & 0.83 \\
\hline
\end{tabular}


TABLE 2 | Continued

\begin{tabular}{|c|c|c|c|c|c|}
\hline $\begin{array}{l}\text { Accession } \\
\text { Number }\end{array}$ & $\begin{array}{l}\text { Gene } \\
\text { Symbol }\end{array}$ & Identified Proteins & $\begin{array}{l}\text { Molecular } \\
\text { Weight }\end{array}$ & $P$ value & $\begin{array}{l}\text { Ratio (KO vs wild- } \\
\text { type) }\end{array}$ \\
\hline P62852 & Rps25 & 40S ribosomal protein $\mathrm{S} 25 \mathrm{OS}=\mathrm{Mus}$ musculus $\mathrm{GN}=\mathrm{Rps} 25 \mathrm{PE}=1 \mathrm{SV}=1$ & $14 \mathrm{kDa}$ & $\begin{array}{c}< \\
0.0001\end{array}$ & 0.83 \\
\hline P84084 & Arf5 & ADP-ribosylation factor $5 \mathrm{OS}=$ Mus musculus $\mathrm{GN}=\mathrm{Arf5} \mathrm{PE}=1 \mathrm{SV}=2$ & $21 \mathrm{kDa}$ & $\begin{array}{c}< \\
0.0001\end{array}$ & 0.83 \\
\hline P10852 & Slc3a2 & 4F2 cell-surface antigen heavy chain OS=Mus musculus GN=Slc3a2 PE=1 SV=1 & $58 \mathrm{kDa}$ & $\begin{array}{c}< \\
0.0001\end{array}$ & 0.83 \\
\hline Q9DC16 & Ergic1 & $\begin{array}{l}\text { Endoplasmic reticulum-Golgi intermediate compartment protein } 1 \mathrm{OS}=\text { Mus musculus } \\
\mathrm{GN}=\text { Ergic } 1 \mathrm{PE}=1 \mathrm{SV}=1\end{array}$ & $33 \mathrm{kDa}$ & $\begin{array}{c}< \\
0.0001\end{array}$ & 0.83 \\
\hline Q9JJI8 & Rpl38 & $60 S$ ribosomal protein L38 OS=Mus musculus GN=Rpl38 PE=1 SV=3 & $8 \mathrm{kDa}$ & $\begin{array}{c}< \\
0.0001\end{array}$ & 0.83 \\
\hline P50096 & Impdh1 & $\begin{array}{l}\text { Inosine-5'-monophosphate dehydrogenase } 1 \mathrm{OS}=\text { Mus musculus } \mathrm{GN}=\mathrm{Impdh} 1 \mathrm{PE}=1 \\
\mathrm{SV}=2\end{array}$ & $55 \mathrm{kDa}$ & $\begin{array}{c}< \\
0.0001\end{array}$ & 0.83 \\
\hline Q9QYI6 & Dnajb9 & DnaJ homolog subfamily B member 9 OS=Mus musculus GN=Dnajb9 PE=1 SV=2 & $26 \mathrm{kDa}$ & 0.0027 & 0.83 \\
\hline Q91V04 & Tram1 & $\begin{array}{l}\text { Translocating chain-associated membrane protein } 1 \mathrm{OS}=\text { Mus musculus } \mathrm{GN}=\text { Tram } 1 \\
\mathrm{PE}=1 \mathrm{SV}=3\end{array}$ & $43 \mathrm{kDa}$ & $\begin{array}{c}< \\
0.0001\end{array}$ & 0.83 \\
\hline Q9JHH9 & Copz2 & Coatomer subunit zeta-2 OS=Mus musculus GN=Copz2 PE=1 SV=1 & $23 \mathrm{kDa}$ & 0.00093 & 0.83 \\
\hline P25322 & Ccnd1 & G1/S-specific cyclin-D1 OS=Mus musculus GN=Ccnd1 PE=1 SV=1 & $33 \mathrm{kDa}$ & 0.00049 & 0.83 \\
\hline Q922H9 & Znf330 & Zinc finger protein 330 OS=Mus musculus GN=Znf330 PE=1 SV=1 & $36 \mathrm{kDa}$ & 0.00035 & 0.83 \\
\hline Q80UM7 & Mogs & Mannosyl-oligosaccharide glucosidase OS=Mus musculus GN=Mogs PE=1 SV=1 & $92 \mathrm{kDa}$ & $\begin{array}{c}< \\
0.0001\end{array}$ & 0.82 \\
\hline Q99KK2 & Cmas & $\mathrm{N}$-acylneuraminate cytidylyltransferase $\mathrm{OS}=$ Mus musculus $\mathrm{GN}=\mathrm{Cmas} \mathrm{PE}=1 \mathrm{SV}=2$ & $48 \mathrm{kDa}$ & $\begin{array}{c}< \\
0.0001\end{array}$ & 0.82 \\
\hline Q51012 & Slc38a10 & $\begin{array}{l}\text { Putative sodium-coupled neutral amino acid transporter } 10 \mathrm{OS}=\text { Mus musculus } \\
\mathrm{GN}=\mathrm{Slc} 38 \mathrm{a} 10 \mathrm{PE}=1 \mathrm{SV}=2\end{array}$ & $117 \mathrm{kDa}$ & $\begin{array}{c}< \\
0.0001\end{array}$ & 0.82 \\
\hline P62267 & Rps23 & 40S ribosomal protein $\mathrm{S} 23 \mathrm{OS}=$ Mus musculus $\mathrm{GN}=\mathrm{Rps} 23 \mathrm{PE}=1 \mathrm{SV}=3$ & $16 \mathrm{kDa}$ & $\begin{array}{c}< \\
0.0001\end{array}$ & 0.82 \\
\hline P83882 & Rpl36a & 60S ribosomal protein L36a OS=Mus musculus GN=Rpl36a PE=1 SV=2 & $12 \mathrm{kDa}$ & 0.0001 & 0.82 \\
\hline P60867 & Rps20 & 40 S ribosomal protein $\mathrm{S} 20 \mathrm{OS}=\mathrm{Mus}$ musculus $\mathrm{GN}=\mathrm{Rps} 20 \mathrm{PE}=1 \mathrm{SV}=1$ & $13 \mathrm{kDa}$ & 0.0001 & 0.82 \\
\hline Q9D823 & Rpl37 & $60 S$ ribosomal protein L37 OS=Mus musculus GN=Rpl37 PE=3 SV=3 & $11 \mathrm{kDa}$ & 0.0001 & 0.82 \\
\hline Q3TJZ6 & Fam98a & Protein FAM98A OS=Mus musculus GN=Fam98a PE=1 SV=1 & $55 \mathrm{kDa}$ & 0.00012 & 0.82 \\
\hline Q8K221 & Arfip2 & Arfaptin-2 OS=Mus musculus GN=Arfip2 PE=1 SV=2 & $38 \mathrm{kDa}$ & 0.00035 & 0.82 \\
\hline P62862 & Fau & $40 \mathrm{~S}$ ribosomal protein $\mathrm{S} 30 \mathrm{OS}=\mathrm{Mus}$ musculus $\mathrm{GN}=\mathrm{Fau} \mathrm{PE}=1 \mathrm{SV}=1$ & $7 \mathrm{kDa}$ & 0.00035 & 0.82 \\
\hline Q9Z0S9 & Rabac1 & Prenylated Rab acceptor protein $1 \mathrm{OS}=$ Mus musculus $\mathrm{GN}=$ Rabac1 $\mathrm{PE}=1 \mathrm{SV}=1$ & $21 \mathrm{kDa}$ & 0.0039 & 0.82 \\
\hline B9EJR8 & Dnaaf5 & Dynein assembly factor 5 , axonemal $\mathrm{OS}=$ Mus musculus $\mathrm{GN}=$ Dnaaf5 $\mathrm{PE}=1 \mathrm{SV}=1$ & $94 \mathrm{kDa}$ & 0.047 & 0.82 \\
\hline Q9CZB0 & Sdhc & $\begin{array}{l}\text { Succinate dehydrogenase cytochrome b560 subunit, mitochondrial OS=Mus } \\
\text { musculus } \mathrm{GN}=\mathrm{Sdhc} \mathrm{PE}=1 \mathrm{SV}=1\end{array}$ & $18 \mathrm{kDa}$ & 0.016 & 0.82 \\
\hline Q8VDJ3 & Hdllbp & Vigilin OS=Mus musculus GN=Hdlbp PE=1 SV=1 & $142 \mathrm{kDa}$ & $\begin{array}{c}< \\
0.0001\end{array}$ & 0.82 \\
\hline Q8BP67 & Rpl24 & $60 S$ ribosomal protein L24 OS=Mus musculus GN=Rpl24 PE=1 SV=2 & $18 \mathrm{kDa}$ & $\begin{array}{c}< \\
0.0001\end{array}$ & 0.82 \\
\hline Q9D1R9 & Rpl34 & $60 S$ ribosomal protein L34 OS=Mus musculus GN=Rpl34 PE=1 SV=2 & $13 \mathrm{kDa}$ & 0.0001 & 0.82 \\
\hline P45878 & Fkbp2 & Peptidyl-prolyl cis-trans isomerase FKBP2 OS=Mus musculus GN=Fkbp2 PE=1 SV=1 & $15 \mathrm{kDa}$ & $\begin{array}{c}< \\
0.0001\end{array}$ & 0.82 \\
\hline P60202 & Plp1 & Myelin proteolipid protein OS=Mus musculus GN=Plp1 PE=1 SV=2 & $30 \mathrm{kDa}$ & $\begin{array}{c}< \\
0.0001\end{array}$ & 0.82 \\
\hline P33622 & Apoc3 & Apolipoprotein C-III OS=Mus musculus GN=Apoc3 PE=1 SV=2 & $11 \mathrm{kDa}$ & 0.021 & 0.82 \\
\hline Q9DCF9 & Ssr3 & $\begin{array}{l}\text { Translocon-associated protein subunit gamma OS=Mus musculus } \mathrm{GN}=\mathrm{Ssr} 3 \mathrm{PE}=1 \\
\mathrm{SV}=1\end{array}$ & $21 \mathrm{kDa}$ & $\begin{array}{c}< \\
0.0001\end{array}$ & 0.82 \\
\hline Q03157 & Aplp1 & Amyloid-like protein 1 OS=Mus musculus GN=Aplp1 PE=1 SV=1 & $73 \mathrm{kDa}$ & 0.019 & 0.81 \\
\hline Q8Cl11 & Gnl3 & Guanine nucleotide-binding protein-like 3 OS=Mus musculus GN=Gnl3 PE=1 SV=2 & $61 \mathrm{kDa}$ & $\begin{array}{c}< \\
0.0001\end{array}$ & 0.81 \\
\hline Q4PJX1 & Odr4 & Protein odr-4 homolog OS=Mus musculus GN=Odr4 PE=1 SV=2 & $50 \mathrm{kDa}$ & 0.00067 & 0.81 \\
\hline Q91XC8 & Dap & Death-associated protein 1 OS=Mus musculus GN=Dap PE=1 SV=3 & $11 \mathrm{kDa}$ & 0.0065 & 0.81 \\
\hline Q01768 & Nme2 & Nucleoside diphosphate kinase B OS=Mus musculus GN=Nme2 PE=1 SV=1 & $17 \mathrm{kDa}$ & $\begin{array}{c}< \\
0.0001\end{array}$ & 0.81 \\
\hline $\mathrm{COHK80}$ & Arxes2 & $\begin{array}{l}\text { Adipocyte-related X-chromosome expressed sequence } 2 \text { OS=Mus musculus } \\
\text { GN=Arxes2 PE=1 SV=1 }\end{array}$ & $20 \mathrm{kDa}$ & 0.00022 & 0.81 \\
\hline Q80WW9 & Ddrgk1 & DDRGK domain-containing protein $1 \mathrm{OS}=$ Mus musculus $\mathrm{GN}=\mathrm{Ddrgk} 1 \mathrm{PE}=1 \mathrm{SV}=2$ & $36 \mathrm{kDa}$ & 0.0032 & 0.81 \\
\hline
\end{tabular}


TABLE 2 | Continued

\begin{tabular}{|c|c|c|c|c|c|}
\hline $\begin{array}{l}\text { Accession } \\
\text { Number }\end{array}$ & $\begin{array}{l}\text { Gene } \\
\text { Symbol }\end{array}$ & Identified Proteins & $\begin{array}{l}\text { Molecular } \\
\text { Weight }\end{array}$ & $P$ value & $\begin{array}{l}\text { Ratio (KO vs wild- } \\
\text { type) }\end{array}$ \\
\hline P42230 & Stat5a & $\begin{array}{l}\text { Signal transducer and activator of transcription } 5 \mathrm{~A} \text { OS=Mus musculus GN=Stat5a } \\
\mathrm{PE}=1 \mathrm{SV}=1\end{array}$ & $91 \mathrm{kDa}$ & $\begin{array}{c}< \\
0.0001\end{array}$ & 0.81 \\
\hline Q3TMP8 & Tmem38a & $\begin{array}{l}\text { Trimeric intracellular cation channel type } \mathrm{A} O \mathrm{OS}=\text { Mus musculus } \mathrm{GN}=\mathrm{Tmem} 38 \mathrm{a} \mathrm{PE}=1 \\
\mathrm{SV}=2\end{array}$ & $33 \mathrm{kDa}$ & 0.031 & 0.81 \\
\hline Q922Q8 & Lrrc59 & Leucine-rich repeat-containing protein 59 OS=Mus musculus GN=Lrrc59 PE=1 SV=1 & $35 \mathrm{kDa}$ & $\begin{array}{c}< \\
0.0001\end{array}$ & 0.80 \\
\hline O55142 & Rpl35a & $60 S$ ribosomal protein L35a OS=Mus musculus GN=Rpl35a PE=1 SV=2 & $13 \mathrm{kDa}$ & $\begin{array}{c}< \\
0.0001\end{array}$ & 0.80 \\
\hline P61961 & Ufm1 & Ubiquitin-fold modifier $1 \mathrm{OS}=$ Mus musculus GN=Ufm1 PE=1 SV=1 & $9 \mathrm{kDa}$ & 0.00017 & 0.80 \\
\hline P47964 & Rpl36 & $60 S$ ribosomal protein L36 OS=Mus musculus GN=Rpl36 PE=3 SV=2 & $12 \mathrm{kDa}$ & 0.0039 & 0.80 \\
\hline Q99PL5 & Rrbp1 & Ribosome-binding protein $1 \mathrm{OS}=$ Mus musculus GN=Rrbp1 PE=1 SV=2 & $173 \mathrm{kDa}$ & $\begin{array}{c}< \\
0.0001\end{array}$ & 0.80 \\
\hline Q9R0P6 & Sec11a & $\begin{array}{l}\text { Signal peptidase complex catalytic subunit SEC11A OS=Mus musculus GN=Sec11a } \\
\mathrm{PE}=1 \mathrm{SV}=1\end{array}$ & $21 \mathrm{kDa}$ & $\begin{array}{c}< \\
0.0001\end{array}$ & 0.80 \\
\hline Q9CY50 & Ssr1 & Translocon-associated protein subunit alpha OS=Mus musculus $\mathrm{GN}=\mathrm{Ssr} 1 \mathrm{PE}=1 \mathrm{SV}=1$ & $32 \mathrm{kDa}$ & 0.0012 & 0.80 \\
\hline Q9D8S4 & Rexo2 & Oligoribonuclease, mitochondrial OS=Mus musculus GN=Rexo2 PE=1 SV=2 & $27 \mathrm{kDa}$ & $\begin{array}{c}< \\
0.0001\end{array}$ & 0.80 \\
\hline Q8R1L4 & Kdelr3 & ER lumen protein-retaining receptor $3 \mathrm{OS}=$ Mus musculus $\mathrm{GN}=\mathrm{Kdel} 3 \mathrm{PE}=1 \mathrm{SV}=1$ & $25 \mathrm{kDa}$ & 0.00035 & 0.80 \\
\hline P47199 & Cryz & Quinone oxidoreductase OS=Mus musculus GN=Cryz PE=1 SV=1 & $35 \mathrm{kDa}$ & $\begin{array}{c}< \\
0.0001\end{array}$ & 0.79 \\
\hline Q64674 & Srm & Spermidine synthase OS=Mus musculus $\mathrm{GN}=\mathrm{Srm} \mathrm{PE}=1 \mathrm{SV}=1$ & $34 \mathrm{kDa}$ & $\begin{array}{c}< \\
0.0001\end{array}$ & 0.79 \\
\hline Q8K009 & Aldh112 & $\begin{array}{l}\text { Mitochondrial 10-formyltetrahydrofolate dehydrogenase OS=Mus musculus } \\
\mathrm{GN}=\mathrm{Aldh} 12 \mathrm{PE}=1 \mathrm{SV}=2\end{array}$ & $102 \mathrm{kDa}$ & $\begin{array}{c}< \\
0.0001\end{array}$ & 0.79 \\
\hline Q8R1U2 & Cgref1 & $\begin{array}{l}\text { Cell growth regulator with } \mathrm{EF} \text { hand domain protein } 1 \mathrm{OS}=\text { Mus musculus } \mathrm{GN}=\mathrm{Cgref} 1 \\
\mathrm{PE}=1 \mathrm{SV}=1\end{array}$ & $31 \mathrm{kDa}$ & 0.00015 & 0.79 \\
\hline Q8VEL9 & Rem2 & GTP-binding protein REM 2 OS=Mus musculus GN=Rem2 PE=1 SV=2 & $37 \mathrm{kDa}$ & $\begin{array}{c}< \\
0.0001\end{array}$ & 0.79 \\
\hline P21956 & Mfge8 & Lactadherin OS=Mus musculus GN=Mfge8 PE $=1 \mathrm{SV}=3$ & $51 \mathrm{kDa}$ & $\begin{array}{c}< \\
0.0001\end{array}$ & 0.78 \\
\hline Q9D8V7 & Sec11c & $\begin{array}{l}\text { Signal peptidase complex catalytic subunit SEC11C OS=Mus musculus } \mathrm{GN}=\mathrm{Sec} 11 \mathrm{C} \\
\mathrm{PE}=1 \mathrm{SV}=3\end{array}$ & $22 \mathrm{kDa}$ & $\begin{array}{c}< \\
0.0001\end{array}$ & 0.78 \\
\hline Q9CXI5 & Manf & $\begin{array}{l}\text { Mesencephalic astrocyte-derived neurotrophic factor OS=Mus musculus GN=Manf } \\
\mathrm{PE}=1 \mathrm{SV}=1\end{array}$ & $20 \mathrm{kDa}$ & $\begin{array}{c}< \\
0.0001\end{array}$ & 0.78 \\
\hline O70251 & Eef1b & Elongation factor 1-beta OS=Mus musculus GN=Eef1b PE=1 SV=5 & $25 \mathrm{kDa}$ & $\begin{array}{c}< \\
0.0001\end{array}$ & 0.77 \\
\hline Q78XF5 & Ostc & $\begin{array}{l}\text { Oligosaccharyltransferase complex subunit OSTC OS=Mus musculus GN=Ostc PE=1 } \\
\text { SV=1 }\end{array}$ & $17 \mathrm{kDa}$ & 0.0039 & 0.77 \\
\hline Q9CQS8 & Sec61b & $\begin{array}{l}\text { Protein transport protein Sec61 subunit beta OS=Mus musculus } \mathrm{GN}=\mathrm{Sec} 61 \mathrm{~b} P E=1 \\
\mathrm{SV}=3\end{array}$ & $10 \mathrm{kDa}$ & $\begin{array}{c}< \\
0.0001\end{array}$ & 0.77 \\
\hline Q61036 & Pak3 & Serine/threonine-protein kinase PAK 3 OS=Mus musculus GN=Pak3 PE=1 SV=2 & $62 \mathrm{kDa}$ & $\begin{array}{c}< \\
0.0001\end{array}$ & 0.77 \\
\hline Q91X91 & Qprt & $\begin{array}{l}\text { Nicotinate-nucleotide pyrophosphorylase [carboxylating] OS=Mus musculus GN=Qprt } \\
\mathrm{PE}=1 \mathrm{SV}=1\end{array}$ & $32 \mathrm{kDa}$ & 0.0031 & 0.77 \\
\hline Q61941 & Nnt & $\mathrm{NAD}(\mathrm{P})$ transhydrogenase, mitochondrial OS=Mus musculus GN=Nnt PE=1 SV=2 & $114 \mathrm{kDa}$ & $\begin{array}{c}< \\
0.0001\end{array}$ & 0.76 \\
\hline Q05186 & Ren1 & Reticulocalbin-1 OS=Mus musculus $\mathrm{GN}=\mathrm{Rcn} 1 \mathrm{PE}=1 \mathrm{SV}=1$ & $38 \mathrm{kDa}$ & $\begin{array}{c}< \\
0.0001\end{array}$ & 0.76 \\
\hline $\mathrm{COHKG5}$ & Rnaset2a & Ribonuclease T2-A OS=Mus musculus GN=Rnaset2a PE=1 SV=1 & $30 \mathrm{kDa}$ & $\begin{array}{c}< \\
0.0001\end{array}$ & 0.76 \\
\hline Q8K023 & Akr1c18 & $\begin{array}{l}\text { Aldo-keto reductase family } 1 \text { member } \mathrm{C} 18 \mathrm{OS}=\text { Mus musculus } \mathrm{GN}=\mathrm{Akr} 1 \mathrm{c} 18 \mathrm{PE}=1 \\
\mathrm{SV}=2\end{array}$ & $37 \mathrm{kDa}$ & 0.0039 & 0.76 \\
\hline Q8R059 & Gale & UDP-glucose 4-epimerase OS=Mus musculus GN=Gale PE=1 SV=1 & $38 \mathrm{kDa}$ & $\begin{array}{c}< \\
0.0001\end{array}$ & 0.76 \\
\hline P61205 & Arf3 & ADP-ribosylation factor 3 OS=Mus musculus GN=Arf3 PE=2 SV=2 & $21 \mathrm{kDa}$ & $\begin{array}{c}< \\
0.0001\end{array}$ & 0.75 \\
\hline P23927 & Cryab & Alpha-crystallin B chain OS=Mus musculus $\mathrm{GN}=\mathrm{Cryab} \mathrm{PE}=1 \mathrm{SV}=2$ & $20 \mathrm{kDa}$ & 0.0039 & 0.75 \\
\hline Q8BH97 & $\operatorname{Ren} 3$ & Reticulocalbin-3 OS=Mus musculus GN=Rcn3 PE=1 SV=1 & $38 \mathrm{kDa}$ & $\begin{array}{c}< \\
0.0001\end{array}$ & 0.74 \\
\hline Q8CFA2 & Amt & Aminomethyltransferase, mitochondrial $\mathrm{OS}=$ Mus musculus $\mathrm{GN}=\mathrm{Amt} P E=1 \mathrm{SV}=1$ & $44 \mathrm{kDa}$ & $\begin{array}{c}< \\
0.0001\end{array}$ & 0.74 \\
\hline
\end{tabular}


TABLE 2 | Continued

\begin{tabular}{|c|c|c|c|c|c|}
\hline $\begin{array}{l}\text { Accession } \\
\text { Number }\end{array}$ & $\begin{array}{l}\text { Gene } \\
\text { Symbol }\end{array}$ & Identified Proteins & $\begin{array}{l}\text { Molecular } \\
\text { Weight }\end{array}$ & $P$ value & $\begin{array}{l}\text { Ratio (KO vs wild- } \\
\text { type) }\end{array}$ \\
\hline Q922W5 & Pycr1 & $\begin{array}{l}\text { Pyrroline-5-carboxylate reductase } 1 \text {, mitochondrial } O S=\text { Mus musculus } G N=P y c r 1 \\
P E=1 S V=1\end{array}$ & $32 \mathrm{kDa}$ & $\begin{array}{c}< \\
0.0001\end{array}$ & 0.74 \\
\hline P34884 & Mif & Macrophage migration inhibitory factor OS=Mus musculus GN=Mif PE=1 SV=2 & $13 \mathrm{kDa}$ & $\begin{array}{c}< \\
0.0001\end{array}$ & 0.73 \\
\hline Q9D7S7 & Rpl22l1 & 60S ribosomal protein L22-like 1 OS=Mus musculus GN=Rpl22/1 PE=1 SV=1 & $14 \mathrm{kDa}$ & 0.00049 & 0.73 \\
\hline Q9WUT3 & Rps6ka2 & Ribosomal protein S6 kinase alpha-2 OS=Mus musculus GN=Rps6ka2 PE=1 SV=1 & $83 \mathrm{kDa}$ & $\begin{array}{c}< \\
0.0001\end{array}$ & 0.69 \\
\hline Q9D1M7 & Fkbp11 & $\begin{array}{l}\text { Peptidyl-prolyl cis-trans isomerase FKBP11 OS=Mus musculus GN=Fkbp11 PE=1 } \\
\text { SV=1 }\end{array}$ & $22 \mathrm{kDa}$ & $\begin{array}{c}< \\
0.0001\end{array}$ & 0.69 \\
\hline P07759 & Serpina3k & Serine protease inhibitor A3K OS=Mus musculus GN=Serpina3k PE=1 SV=2 & $47 \mathrm{kDa}$ & $\begin{array}{c}< \\
0.0001\end{array}$ & 0.69 \\
\hline Q60841 & Reln & Reelin OS=Mus musculus GN=Reln PE=1 SV=3 & $387 \mathrm{kDa}$ & $\begin{array}{c}< \\
0.0001\end{array}$ & 0.66 \\
\hline P61750 & Arf4 & ADP-ribosylation factor $4 \mathrm{OS}=$ Mus musculus $\mathrm{GN}=\mathrm{Arf} 4 \mathrm{PE}=1 \mathrm{SV}=2$ & $20 \mathrm{kDa}$ & 0.00035 & 0.66 \\
\hline Q60590 & Orm1 & Alpha-1-acid glycoprotein 1 OS=Mus musculus GN=Orm1 PE=1 SV=1 & $24 \mathrm{kDa}$ & 0.00035 & 0.66 \\
\hline P47212 & Gal & Galanin peptides $\mathrm{OS}=$ Mus musculus $\mathrm{GN}=\mathrm{Gal} \mathrm{PE}=2 \mathrm{SV}=1$ & $13 \mathrm{kDa}$ & 0.0039 & 0.65 \\
\hline P51667 & Myl2 & $\begin{array}{l}\text { Myosin regulatory light chain 2, ventricular/cardiac muscle isoform OS=Mus musculus } \\
\mathrm{GN}=\mathrm{Myl} 2 \mathrm{PE}=1 \mathrm{SV}=3\end{array}$ & $19 \mathrm{kDa}$ & $\begin{array}{c}< \\
0.0001\end{array}$ & 0.64 \\
\hline P06879 & $\mathrm{Prl}$ & Prolactin OS=Mus musculus GN=Prl PE=2 SV=1 & $25 \mathrm{kDa}$ & $\begin{array}{c}< \\
0.0001\end{array}$ & 0.61 \\
\hline Q640N1 & Aebp1 & Adipocyte enhancer-binding protein $1 \mathrm{OS}=$ Mus musculus $\mathrm{GN}=\mathrm{Aebp} 1 \mathrm{PE}=1 \mathrm{SV}=1$ & $128 \mathrm{kDa}$ & $\begin{array}{c}< \\
0.0001\end{array}$ & 0.57 \\
\hline Q60571 & Crhbp & $\begin{array}{l}\text { Corticotropin-releasing factor-binding protein OS=Mus musculus GN=Crhbp PE=2 } \\
\mathrm{SV}=1\end{array}$ & $36 \mathrm{kDa}$ & 0.00035 & 0.53 \\
\hline P09542 & Myl3 & Myosin light chain 3 OS=Mus musculus GN=Myl3 PE=1 SV=4 & $22 \mathrm{kDa}$ & 0.00035 & 0.46 \\
\hline
\end{tabular}

mutant pituitary by $72 \%$ may compensate for the deficiency in the secretory mechanisms of the mutant mice (Figure 7C), which may also explain the fertility of male mutant mice. There is much agreement that FSH influences the mitotic activity of the spermatogonia and promote cellular differentiation during the pubertal phase (61). Testosterone regulated by LH also plays a role for spermatogenesis, however, completely $\mathrm{T}$-independent spermatogenesis is possible if high-dose FSH treatment (62).

Of note, the use of intraventricular injection of $m i R-29$ inhibitor or overexpression of an antisense sequence targeting $m i R-29$ in the brain to knockdown expression of $m i R-29$ leads to earlier puberty onset or hyperfertility (63). These findings are not consistent with our results. It is possible that lack of $m i R-29 a / b_{1}$ function throughout development could result in compensatory effects which may lead to differences between our results and the results of the above literature. The underlying reasons for the different effects between knockout and knockdown need to be further studied. In addition, it should be noted that KO mice also showed growth retardation (64). We found that the weight of $\mathrm{KO}$ mice remained light, even though they had reached sexual maturity. So, the causal relation between two events cannot be confirmed now. We speculated that growth retardation and delayed maturity may come from the same reason, which happened in pituitary or upstream signal of $\mathrm{KO}$ mice.

In conclusion, LH secretion was impaired by $m i R-29 a / b_{1}$ knockout which caused ovulation deficiency in the mutant mice. Further studies revealed the effect of $m i R-29 a / b_{1}$ on hormone secretion function in the pituitary. Our work provides novel mechanistic insights into the relationship of
miR-29a/b and reproduction, opening the possibility of clinical approaches to reproductive studies based on the regulatory circuitry of $m i R-29 a / b_{1}$.

\section{DATA AVAILABILITY STATEMENT}

The datasets presented in this study can be found in online repositories. The names of the repository/repositories and accession number(s) can be found in the article/Supplementary Material.

\section{ETHICS STATEMENT}

The animal study was reviewed and approved by Institutional Animal Care and Use Committee of Shanghai Engineering Research Center for Model Organisms, SMOC. Written informed consent was obtained from the owners for the participation of their animals in this study.

\section{AUTHOR CONTRIBUTIONS}

YG, RSu, RSh and JF designed research. YG and JF analyzed data. YG, YW, HS, HZ, LC, QH, ZhiW, and YT performed research. YG, LX and JF wrote the paper. HY, MZ and ZhuW contributed to discussion and the proof reading of the paper. All authors contributed to the article and approved the submitted version. 


\section{FUNDING}

This work was supported by the grants from National Natural Science Foundation. of China (81261120568) and Science and Technology Commission of Shanghai Municipality (19DZ2280500, 18DZ2293500).

\section{ACKNOWLEDGMENTS}

We thank Ms. Shen Jiajuan for laboratory management.

\section{SUPPLEMENTARY MATERIAL}

The Supplementary Material for this article can be found online at: https://www.frontiersin.org/articles/10.3389/fendo.2021.636220/ full\#supplementary-material

\section{Supplementary Table 1 | List of oligonucleotides used.}

Supplementary Figure 1 | Genotyping of miR-29a/b, KO knockout mice. (A) The genotype of $m i R-29 a / b, K O$ was identified by PCR amplification. There was $600 \mathrm{bp}$ deleted from the genomic DNA of miR-29a/b, . +/+: wild-type, +/-: heterozygous, -/-: homozygous. (B) Mature miR-29a RNA was detected in different tissues of wild-type mice but not in those of homozygous knockout mice $(n=3)$. The precursor of miR-29a (C) and miR-29b 1 (D) RNA level was measured by quantitative RT-PCR in different tissues. Pre-miR-29a or pre-miR-29b, levels were decreased in miR-29a/ $/ b_{1}{ }^{+/-}$mice $(n=10)$ and hardly detected in miR-29a/ $b_{1}{ }^{-1-}$ mice $(n=10)$ compared to wild-type littermates $(n=8)$.

Supplementary Figure 2 | Representative cell morphological changes in vaginal smears and estrous cycle pattern of four female mice in each wild-type and miR$29 a / b_{1}$ KO groups are shown

Supplementary Figure 3 | miR-29a expression patterns. (A) miR-29a expression patterns in wild-type mice during the estrous cycle in pituitary and ovary tissues ( $n=10$ ). 1, proestrus; 2, estrus; 3, metestrus; 4, diestrus. (B) Relative expression levels of miR-29a, miR-29b and miR-29c in hypothalamus, pituitary and gonad (HPG axis) of wild-type and miR-29a/b, KO mice (omiR-29c: hypothalamus: $p=0.6648$, pituitary: $p=0.4896$, ovary: $p=0.8028$, omiR-29c: hypothalamus: $p=0.0727$, pituitary: $p=0.1225$, testis: $p=0.5042, n=5$ ).

Supplementary Figure 4 | Wet testis and seminal vesicle (SV) weight in males, normalized to body weight in the same animals (testis: wild-type: $0.7234 \pm$ $0.02481, \mathrm{n}=8, \mathrm{miR}-29 \mathrm{a} / \mathrm{b}_{1} \mathrm{KO}: 0.9563 \pm 0.03834, \mathrm{n}=9, p=0.2107$; seminal: wild-type: $0.6085 \pm 0.07193, \mathrm{n}=8, \mathrm{miR}-29 \mathrm{a} / \mathrm{b}_{1} \mathrm{KO}: 0.5191 \pm 0.03874, \mathrm{n}=9$, $p=0.2764)$.

Supplementary Figure 5 | Levels of selected hormones in females. (A-C) Serum FSH (wild-type: $12.23 \pm 1.415, \mathrm{n}=8$, miR-29a/b, KO: $13.62 \pm$ 1.255, $n=13, p=0.4850$ ) (A) and Testosterone (wild-type: $2.774 \pm 0.1147$, $\mathrm{n}=10$, miR-29a/b, KO: $2.711 \pm 0.2052, \mathrm{n}=9, p=0.7867)$. (B) and Estradiol (wild-type: $207.9 \pm 13.89, \mathrm{n}=17, \mathrm{miR}-29 \mathrm{a} / \mathrm{b}_{1} \mathrm{KO}: 179.3 \pm 15.54, \mathrm{n}=19$, $p=0.1834)$. (C) of wild-type and $m i R-29 a / b_{1} \mathrm{KO}$ mice were determined. (D) Expression of hormone synthesis-related gene in the ovaries in wild-type $(\mathrm{n}=4)$ and $\mathrm{miR}-29 \mathrm{a} / \mathrm{b}_{1} \mathrm{KO}(\mathrm{n}=10)$ females (cyp11a: $p=0.0159$, cyp17a $p=0.6094$, cyp19a $: p=0.9604)$.

\section{REFERENCES}

1. Caravia XM, Fanjul V, Oliver E, Roiz-Valle D, Moran-Alvarez A, DesdinMico G, et al. The microRNA-29/PGClalpha Regulatory Axis is Critical for Metabolic Control of Cardiac Function. PloS Biol (2018) 16(10):e2006247. doi: 10.1371/journal.pbio.2006247

2. Kurtz CL, Fannin EE, Toth CL, Pearson DS, Vickers KC, Sethupathy P. Inhibition of miR-29 has a Significant Lipid-Lowering Benefit Through Suppression of Lipogenic Programs in Liver. Sci Rep (2015) 5:12911. doi: $10.1038 /$ srep 12911

3. Kurtz CL, Peck BC, Fannin EE, Beysen C, Miao J, Landstreet SR, et al. MicroRNA29 Fine-Tunes the Expression of Key FOXA2-activated Lipid Metabolism Genes and is Dysregulated in Animal Models of Insulin Resistance and Diabetes. Diabetes (2014) 63(9):3141-8. doi: 10.2337/db13-1015

4. Brain O, Owens BM, Pichulik T, Allan P, Khatamzas E, Leslie A, et al. The Intracellular Sensor NOD2 Induces microRNA-29 Expression in Human Dendritic Cells to Limit IL-23 Release. Immunity (2013) 39(3):521-36. doi: 10.1016/j.immuni.2013.08.035

5. Zhou Q, Costinean S, Croce CM, Brasier AR, Merwat S, Larson SA, et al. MicroRNA 29 Targets Nuclear factor-kappaB-repressing Factor and Claudin 1 to Increase Intestinal Permeability. Gastroenterology (2015) 148(1):15869.e158. doi: 10.1053/j.gastro.2014.09.037

6. Cushing L, Kuang P and Lu J. The Role of miR-29 in Pulmonary Fibrosis. Biochem Cell Biol (2015) 93(2):109-18. doi: 10.1139/bcb-2014-0095

7. Jiang H, Zhang G, Wu JH, Jiang CP. Diverse Roles of miR-29 in Cancer (Review). Oncol Rep (2014) 31(4):1509-16. doi: 10.3892/or.2014.3036

8. Papadopoulou AS, Serneels L, Achsel T, Mandemakers W, Callaerts-Vegh Z, Dooley J, et al. Deficiency of the miR-29a/b-1 Cluster Leads to Ataxic Features and Cerebellar Alterations in Mice. Neurobiol Dis (2015) 73:275-88. doi: 10.1016/j.nbd.2014.10.006

9. Juzwik CA, S D S, Zhang Y, Paradis-Isler N, Sylvester A, Amar-Zifkin A, et al. microRNA Dysregulation in Neurodegenerative Diseases: A Systematic Review. Prog Neurobiol (2019) 182:101664. doi: 10.1016/j.pneurobio.2019.101664

10. Serafin A, Foco L, Zanigni S, Blankenburg H, Picard A, Zanon A, et al. Overexpression of Blood microRNAs 103a, 30b, and 29a in L-dopa-treated Patients With PD. Neurology (2015) 84(7):645-53. doi: 10.1212/WNL.00 00000000001258

11. Zhao YY, Duan RN, Ji L, Liu QJ, Yan CZ. Cervical Spinal Involvement in a Chinese Pedigree With Pontine Autosomal Dominant Microangiopathy and Leukoencephalopathy Caused by a 3' Untranslated Region Mutation of COL4A1 Gene. Stroke (2019) 50(9):2307-13. doi: 10.1161/STROKEAHA.119.024875

12. Ulrich V, Rotllan N, Araldi E, Luciano A, Skroblin P, Abonnenc M, et al. Chronic miR-29 Antagonism Promotes Favorable Plaque Remodeling in Atherosclerotic Mice. EMBO Mol Med (2016) 8(6):643-53. doi: 10.15252/ emmm.201506031

13. Mattis AN, Song G, Hitchner K, Kim RY, Lee AY, Sharma AD, et al. A Screen in Mice Uncovers Repression of Lipoprotein Lipase by microRNA-29a as a Mechanism for Lipid Distribution Away From the Liver. Hepatology (2015) 61 (1):141-52. doi: 10.1002/hep.27379

14. Hu W, Dooley J, Chung SS, Chandramohan D, Cimmino L, Mukherjee S, et al. miR-29a Maintains Mouse Hematopoietic Stem Cell Self-Renewal by Regulating Dnmt3a. Blood (2015) 125(14):2206-16. doi: 10.1182/blood2014-06-585273

15. Glantschnig C, Koenen M, Gil-Lozano M, Karbiener M, Pickrahn I, WilliamsDautovich J, et al. A miR-29a-driven Negative Feedback Loop Regulates Peripheral Glucocorticoid Receptor Signaling. FASEB J (2019) 33(5):5924-41. doi: $10.1096 /$ fj.201801385RR

16. Takeda $\mathrm{T}$ and Tanabe H. Lifespan and Reproduction in Brain-Specific miR29-knockdown Mouse. Biochem Biophys Res Commun (2016) 471(4):454-8. doi: 10.1016/j.bbrc.2016.02.055

17. Liao Y, Ouyang L, Ci L, Chen B, Lv D, Li Q, et al. Pravastatin Regulates Host ForeignBody Reaction to Polyetheretherketone Implants Via Mir-29ab1-Mediated SLIT3 Upregulation. Biomaterials (2019) 203:12-22. doi: 10.1016/ j.biomaterials.2019.02.027

18. Parkening TA, Collins TJ, Smith ER. Plasma and Pituitary Concentrations of LH, FSH, and Prolactin in Aging C57BL/6 Mice at Various Times of the Estrous Cycle. Neurobiol Aging (1982) 3(1):31-5. doi: 10.1016/0197-4580(82)90058-6 
19. Hoffmann HM, Tamrazian A, Xie H, Pérez-Millán MI, Kauffman AS, Mellon PL. Heterozygous Deletion of Ventral Anterior Homeobox (Vax1) Causes Subfertility in Mice. Endocrinology (2014) 155(10):4043-53. doi: 10.1210/en.2014-1277

20. Ding J, Tan X, Song K, Ma W, Xiao J and Zhang M. Effect of Controlled Ovarian Hyperstimulation on Puberty and Estrus in Mice Offspring. Reproduction (2017) 154(4):433-44. doi: 10.1530/REP-16-0572

21. Perez-Riverol Y, Csordas A, Bai J, Bernal-Llinares M, Hewapathirana S, Kundu DJ, et al. The PRIDE Database and Related Tools and Resources in 2019: Improving Support for Quantification Data. Nucleic Acids Res (2019) 47 (D1):D442-50. doi: 10.1093/nar/gkyl106

22. Pedersen $\mathrm{T}$ and Peters H. Proposal for a Classification of Oocytes and Follicles in the Mouse Ovary. J Reprod Fertil (1968) 17(3):555-7. doi: 10.1530/jrf.0.0170555

23. Johnson J, Canning J, Kaneko T, Pru JK, Tilly JL. Germline Stem Cells and Follicular Renewal in the Postnatal Mammalian Ovary. Nature (2004) 428 (6979):145-50. doi: 10.1038/nature02316

24. Doroszko M, Chrusciel M, Stelmaszewska J, Slezak T, Anisimowicz S, Plöckinger U, et al. GnRH Antagonist Treatment of Malignant Adrenocortical Tumors. Endocr Relat Cancer (2019) 26(1):103-17. doi: 10.1530/ERC-17-0399

25. Torrealday S, Lalioti MD, Guzeloglu-Kayisli O, Seli E. Characterization of the Gonadotropin Releasing Hormone Receptor (GnRHR) Expression and Activity in the Female Mouse Ovary. Endocrinology (2013) 154(10):387787. doi: 10.1210/en.2013-1341

26. Murányi J, Varga A, Gyulavári P, Pénzes K, Németh CE, Csala M, et al. Novel Crizotinib-GnRH Conjugates Revealed the Significance of Lysosomal Trapping in GnRH-Based Drug Delivery Systems. Int J Mol Sci (2019) 20 (22):5590. doi: 10.3390/ijms20225590

27. Strich S. Atlas of the Mouse Brain and Spinal Cord. Journal of Neurology. Neurosurgery Psychiatry (1972) 35(3):422. doi: 10.1136/jnnp.35.3.422-b

28. Livak KJ, Schmittgen TD. Analysis of Relative Gene Expression Data Using Real-Time Quantitative PCR and the 2(-Delta Delta C(T)) Method. Methods (2001) 25(4):402-8. doi: 10.1006/meth.2001.1262

29. Quirk SM, Cowan RG, Harman RM. Role of the Cell Cycle in Regression of the Corpus Luteum. Reproduction (2013) 145(2):161-75. doi: 10.1530/REP-12-0324

30. Hrabovszky E, Kalló I, Szlávik N, Keller E, Merchenthaler I, Liposits Z. Gonadotropin-Releasing Hormone Neurons Express Estrogen Receptor-Beta. J Clin Endocrinol Metab (2007) 92(7):2827-30. doi: 10.1210/jc.2006-2819

31. Hrabovszky E, Shughrue PJ, Merchenthaler I, Hajszán T, Carpenter CD, Liposits Z, et al. Detection of Estrogen Receptor-Beta Messenger Ribonucleic Acid and 125I-Estrogen Binding Sites in Luteinizing Hormone-Releasing Hormone Neurons of the Rat Brain. Endocrinology (2000) 141(9):3506-9. doi: 10.1210/endo.141.9.7788

32. Adams C, Stroberg W, Defazio RA, Schnell S and Moenter SM. Gonadotropin-Releasing Hormone (Gnrh) Neuron Excitability Is Regulated by Estradiol Feedback and Kisspeptin. J Neurosci (2018) 38(5):1249. doi: 10.1523/JNEUROSCI.2988-17.2017

33. Farkas I, Bálint F, Farkas E, Vastagh C, Fekete C and Liposits Z. Estradiol Increases Glutamate and GABA Neurotransmission Into GnRH Neurons Via Retrograde No-Signaling in Proestrous Mice During the Positive Estradiol Feedback Period. Eneuro (2018) 5(4):ENEURO.0057-0018.2018. doi: 10.1523/ENEURO.0057-18.2018

34. Smith JT, Dungan HM, Stoll EA, Gottsch ML, Braun RE, Eacker SM, et al. Differential Regulation of KiSS-1 Mrna Expression by Sex Steroids in the Brain of the Male Mouse. Endocrinology (2005) 146(7):2976-84. doi: 10.1210/en.2005-0323

35. Mittelman-Smith MA, Krajewski-Hall SJ, Mcmullen NT, Rance NE. Ablation of KNDy Neurons Results in Hypogonadotropic Hypogonadism and Amplifies the Steroid-Induced Lh Surge in Female Rats. Endocrinology (2016) 157(5):2015-27. doi: 10.1210/en.2015-1740

36. Clarkson J, Anglemont De Tassigny X, Moreno AS, Colledge WH, Herbison AE. Kisspeptin-GPR54 Signaling is Essential for Preovulatory GonadotropinReleasing Hormone Neuron Activation and the Luteinizing Hormone Surge. J Neurosci (2008) 28(35):8691. doi: 10.1523/JNEUROSCI.1775-08.2008

37. Smith JT, Cunningham MJ, Rissman EF, Clifton DK, Steiner RA. Regulation of Kiss1 Gene Expression in the Brain of the Female Mouse. Endocrinology (2005) 146(9):3686-92. doi: 10.1210/en.2005-0488

38. Abreu AP, Kaiser UB. Pubertal Development and Regulation. Lancet Diabetes Endocrinol (2016) 4(3):254-64. doi: 10.1016/S2213-8587(15)00418-0

39. Peters GA, Seachrist DD, Keri RA, Sen GC. The Double-Stranded RNA-binding Protein, $\mathrm{PACT}$, is Required for Postnatal Anterior Pituitary Proliferation. Proc
Natl Acad Sci United States America (2009) 106(26):10696-701. doi: 10.1073/ pnas.0900735106

40. Goldberg J. Structural Basis for Activation of ARF Gtpase: Mechanisms of Guanine Nucleotide Exchange and GTP-myristoyl Switching. Cell (1998) 95 (2):237-48. doi: 10.1016/S0092-8674(00)81754-7

41. Gustafson MA, Fromme JC. Regulation of Arf Activation Occurs Via Distinct Mechanisms at Early and Late Golgi Compartments. Mol Biol Cell (2017) 28 (25):3660-71. doi: 10.1091/mbc.e17-06-0370

42. Trychta KA, Back S, Henderson MJ, Harvey BK. Kdel Receptors are Differentially Regulated to Maintain the ER Proteome Under Calcium Deficiency. Cell Rep (2018) 25(7):1829-40.e1826. doi: 10.1016/j.celrep.2018.10.055

43. An Q, Liu T, Wang MY, Yang YJ, Zhang ZD, Lin ZJ, et al. Circkrt7-Mir-29a3p-COL1A1 Axis Promotes Ovarian Cancer Cell Progression. Onco Targets Ther (2020) 13:8963-76. doi: 10.2147/OTT.S259033

44. Hu X, Tan S, Yin H, Khoso PA, Xu Z and Li S. Selenium-Mediated gga-miR-29a3p Regulates LMH Cell Proliferation, Invasion, and Migration by Targeting COL4A2. Metallomics (2020) 12(3):449-59. doi: 10.1039/C9MT00266A

45. Zhao B, Song $X$ and Guan H. CircACAP2 Promotes Breast Cancer Proliferation and Metastasis by Targeting miR-29a/b-3p-COL5A1 Axis. Life Sci (2020) 244:117179. doi: 10.1016/j.lfs.2019.117179

46. Ma R, Wang M, Gao S, Zhu L, Yu L, Hu D, et al. Mir-29a Promotes the Neurite Outgrowth of Rat Neural Stem Cells by Targeting Extracellular Matrix to Repair Brain Injury. Stem Cells Dev (2020) 29(9):599-614. doi: 10.1089/scd.2019.0174

47. Long KR, Newland B, Florio M, Kalebic N, Langen B, Kolterer A, et al. Extracellular Matrix Components HAPLN1, Lumican, and Collagen I Cause Hyaluronic Acid-Dependent Folding of the Developing Human Neocortex. Neuron (2018) 99(4):702-19.e706. doi: 10.1016/j.neuron.2018.07.013

48. Lin CL, Lee PH, Hsu YC, Lei CC, Ko JY, Chuang PC, et al. MicroRNA-29a Promotion of Nephrin Acetylation Ameliorates Hyperglycemia-Induced Podocyte Dysfunction. J Am Soc Nephrol (2014) 25(8):1698-709. doi: 10.1681/ASN.2013050527

49. Reinstein E, Drasinover V, Lotan R, Gal-Tanamy M, Bolocan Nachman I, Eyal E, et al. Mutations in ERGIC1 Cause Arthrogryposis Multiplex Congenita, Neuropathic Type. Clin Genet (2018) 93(1):160-3. doi: 10.1111/cge.13018

50. Dittner-Moormann S, Lourenco CM, Reunert J, Nishinakamura R, Tanaka SS, Werner C, et al. Trap $\gamma$-CDG Shows Asymmetric Glycosylation and an Effect on Processing of Proteins Required in Higher Organisms. J Med Genet (2021) 58(3):213-6. doi: 10.1136/jmedgenet-2019-106279

51. Bond LM, Brandstaetter H, Sellers JR, Kendrick-Jones J, Buss F. Myosin Motor Proteins are Involved in the Final Stages of the Secretory Pathways. Biochem Soc Trans (2011) 39(5):1115-9. doi: 10.1042/BST0391115

52. Rao K, Paik WY, Zheng L, Jobin RM, Tomic M, Jiang H, et al. WortmanninSensitive and -Insensitive Steps in Calcium-Controlled Exocytosis in Pituitary Gonadotrophs: Evidence That Myosin Light Chain Kinase Mediates CalciumDependent and Wortmannin-Sensitive Gonadotropin Secretion. Endocrinology (1997) 138(4):1440-9. doi: 10.1210/endo.138.4.5078

53. Meysing AU, Kanasaki H, Bedecarrats GY, Acierno JS, Conn PM, Martin KA, et al. GNRHR Mutations in a Woman With Idiopathic Hypogonadotropic Hypogonadism Highlight the Differential Sensitivity of Luteinizing Hormone and Follicle-Stimulating Hormone to Gonadotropin-Releasing Hormone. J Clin Endocrinol Metab (2004) 89(7):3189-98. doi: 10.1210/jc.2003-031808

54. Marshall JC, Kelch RP. Gonadotropin-Releasing Hormone: Role of Pulsatile Secretion in the Regulation of Reproduction. New Engl J Med (1986) 315 (23):1459-68. doi: 10.1056/NEJM198612043152306

55. Stamatiades GA, Kaiser UB. Gonadotropin Regulation by Pulsatile GnRH: Signaling and Gene Expression. Mol Cell Endocrinol (2018) 463:131-41. doi: 10.1016/j.mce.2017.10.015

56. Li C, Liu Z, Li W, Zhang L, Zhou J, Sun M, et al. The FSH-HIF-1 $\alpha$-Vegf Pathway is Critical for Ovulation and Oocyte Health But Not Necessary for Follicular Growth in Mice. Endocrinology (2020) 161(4):bqaa038. doi: 10.1210/endocr/ bqaa038

57. Demeestere I, Streiff AK, Suzuki J, Al-Khabouri S, Mahrous E, Tan SL, et al. Follicle-Stimulating Hormone Accelerates Mouse Oocyte Development In Vivo. Biol Reprod (2012) 87(1):3, 1-11. doi: 10.1095/biolreprod.112.099929

58. Fauser BC. Follicular Development and Oocyte Maturation in Hypogonadotrophic Women Employing Recombinant Follicle-Stimulating Hormone: The Role of Oestradiol. Hum Reprod Update (1997) 3(2):101-8. doi: 10.1093/humupd/3.2.101 
59. Anderson L. Intracellular Mechanisms Triggering Gonadotrophin Secretion. Rev Reprod (1996) 1(3):193-202. doi: 10.1530/ror.0.0010193

60. Duran-Pasten ML, Fiordelisio T. Gnrh-Induced $\mathrm{Ca}(2+)$ Signaling Patterns and Gonadotropin Secretion in Pituitary Gonadotrophs. Functional Adaptations to Both Ordinary and Extraordinary Physiological Demands. Front Endocrinol (Lausanne) (2013) 4:127. doi: 10.3389/fendo.2013.00127

61. Foresta C, Selice R, Ferlin A, Arslan P and Garolla A. Hormonal Treatment of Male Infertility: FSH. Reprod BioMed Online (2007) 15(6):666-72. doi: 10.1016/S1472-6483(10)60533-0

62. Oduwole OO, Peltoketo H, Poliandri A, Vengadabady L, Chrusciel M, Doroszko $\mathrm{M}$, et al. Constitutively Active Follicle-Stimulating Hormone Receptor Enables Androgen-Independent Spermatogenesis. J Clin Invest (2018) 128(5):1787-92. doi: 10.1172/JCI96794

63. Li X, Xiao J, Fan Y, Yang K, Li K, Wang X, et al. miR-29 Family Regulates the Puberty Onset Mediated by a Novel Gnrh1 Transcription Factor TBX21. J Endocrinol (2019) 242(3):185-97. doi: 10.1530/JOE-19-0082
64. Majarune S, Nima P, Sugimoto A, Nagae M, Inoue N, Tsukamura H, et al. Ad Libitum Feeding Triggers Puberty Onset Associated With Increases in Arcuate Kiss1 and Pdyn Expression in Growth-Retarded Rats. J Reprod Dev (2019) 65(5):397-406. doi: 10.1262/jrd.2019-048

Conflict of Interest: The authors declare that the research was conducted in the absence of any commercial or financial relationships that could be construed as a potential conflict of interest.

Copyright $\odot 2021$ Guo, Wu, Shi, Zhuang, Ci, Huang, Wan, Yang, Zhang, Tan, Sun, $\mathrm{Xu}$, Wang, Shen and Fei. This is an open-access article distributed under the terms of the Creative Commons Attribution License (CC BY). The use, distribution or reproduction in other forums is permitted, provided the original author(s) and the copyright owner(s) are credited and that the original publication in this journal is cited, in accordance with accepted academic practice. No use, distribution or reproduction is permitted which does not comply with these terms. 